\title{
Is interactive air sea coupling relevant for simulating the future climate of Europe?
}

\author{
M. Gröger ${ }^{1}$ (1) $\cdot$ C. Dieterich ${ }^{2} \cdot$ H. E. M. Meier ${ }^{1,2}$
}

Received: 26 March 2020 / Accepted: 3 October 2020 / Published online: 12 October 2020

(C) The Author(s) 2020

\begin{abstract}
The majority of regional climate change assessments for the Euro-CORDEX region is based on high resolution atmosphere models. These models use prescribed lower boundary conditions, such as sea surface temperatures (SST) from global ocean General Circulation Models (GCMs), that do not respond to changes simulated by the regional atmosphere model, thus lacking an important feedback to the atmosphere. However, research during the past decade indicated that the use of coupled atmosphere-ocean models can lead to significantly altered model solutions compared to standalone atmosphere models for the present day climate imposing some uncertainty on the widely used uncoupled future scenarios. We here present the first multi-model and multi scenario (RCP2.6, RCP4.5, RCP8.5) ensemble of future climate change scenarios downscaled with a coupled atmosphere - ocean model in which sea surface temperature and sea ice fields are explicitly simulated by a coupled state-of-the-art high resolution ocean model and communicated to the atmosphere at 3-hourly time steps. Our ensemble generally confirms results of previous uncoupled ensembles over land areas implying that the coupling effect is restricted mainly to the coupled area and the adjacent coastal zone. By contrast, over the North Sea and Baltic Sea small scale processes point to important coupling effects that mediate the response to climate change and that can not be simulated by uncoupled models. Our results therefore impose general uncertainty on the usage of regional climate change data from uncoupled ensembles over marine areas such as for purposes of offshore wind or mussel farming, the planing of marine protected areas, and marine recreation along the coastal zone. It further sets in question the usage of uncoupled scenario data (such as Euro-CORDEX) to force high resolution ocean models. Comparing coupled and uncoupled hindcast simulations reveals that the coupling effect over land is most pronounced during the warm season when prescribed and modelled sea surface temperatures (SST) differ strongest. In addition, a generally weaker wind regime in summer damps the heat dispersion in the atmosphere so that air temperature anomalies can extent further over land compared to winter. Future projections are discussed under consideration of land-sea warming characteristics for selected climate indices as well as mean seasonal climate change. At the end of the century a clear land-sea pattern is seen in all scenarios with stronger warming over land than over open sea areas. On average land areas warm at a rate 1.5 times faster than areas over the open ocean. Over the coupled area, i.e. the North Sea and Baltic Sea tropical nights are impacted strongest and the Baltic Sea turns out to be a hot spot in future climate. This has been unrecognized in previous studies using high resolution atmosphere models with prescribed SSTs from global models which do not represent small scale ocean processes in the Baltic Sea adequately.
\end{abstract}

\section{Introduction}

Electronic supplementary material The online version of this article (https://doi.org/10.1007/s00382-020-05489-8) contains supplementary material, which is available to authorized users.

M. Gröger

matthias.groeger@io-warnemuende.de

1 Leibniz Institute for Baltic Sea Research Warnemünde, Rostock, Germany

2 Swedish Meteorological and Hydrological Institute, Norrköping, Sweden
Climate change projections are still subject to large uncertainties. Therefore, they are assessed by large model ensembles. These ensembles cover a range of different possible pathways for future climate forcing such as greenhouse gases and aerosols and are realized by as many as possible global climate or Earth System Models (ESMs). On the regional scale such efforts have been coordinated within the CORDEX framework (Giorgi et al. 2006) which harmonizes forcings, model domains, and even gives recommendations for 
the analysis of model simulations. So far, CORDEX activities have resulted in many improvements to simulate the present day climate with high resolution climate models set up for many regions of the world (e.g. Adloff et al. 2017; Akhtar et al. 2017; Choudhary and Dimri 2017; Ho-Hagemann et al. 2017; Poan et al. 2017; Dosio et al. 2019; Primo et al. 2019). More recent CORDEX activities likewise addressed the problem of future climate change by downscaling available global climate simulations from the Coupled Model Intercomparison Project (CMIP). For the European sector a growing number of studies exists that investigates the climate change impacts on various variables and for specific European regions (e.g. Pfeifer et al. 2015; Bartók et al. 2017; Frei et al. 2018; Hosseinzadehtalaei et al. 2018; Kjellström et al. 2018; Potopová et al. 2018; Cardoso et al. 2019; Boé et al. 2020; Casanueva et al. 2020).

Comprehensive analysis of regional high resolution climate scenarios is provided by a number of different studies (e.g. Jacob et al. 2014, 2018; Rajczak and Schär 2017; Kjellström et al. 2018). Both Jacob et al. (2014) and Kjellström et al. (2018) found that uncertainty associated with the choice of the scenario is by far larger for temperature based climate indices than for precipitation based indices. However, the two studies did not consider the climate scenario $\mathrm{RCP} 2.6$ which projects the radiative forcing to be lower by $40 \%$ compared to RCP4.5 in year 2100 . Consequently, the aforementioned studies do not investigate the effect of rigorous mitigation efforts on which the RCP2.6 scenario was build on.

RCP2.6 is based on mitigation scenarios that aim at limiting global mean warming to $+2 \mathrm{~K}$ (van Vuuren et al. 2007, 2011). This scenario assumes peak emissions already around 2020 (Fig. 1) and negative emissions after 2075. Indeed, the IPCC AR5 report gives a likely range of a $0.3-1.7 \mathrm{~K}$ warming of the global mean temperature at the end of the twentyfirst century relative to 1986-2005 period (IPCC 2013).

RCP4.5 has been developed as moderate mitigation scenario. It assumes changes in the energy system, including shifts to electricity, lower emissions of energy

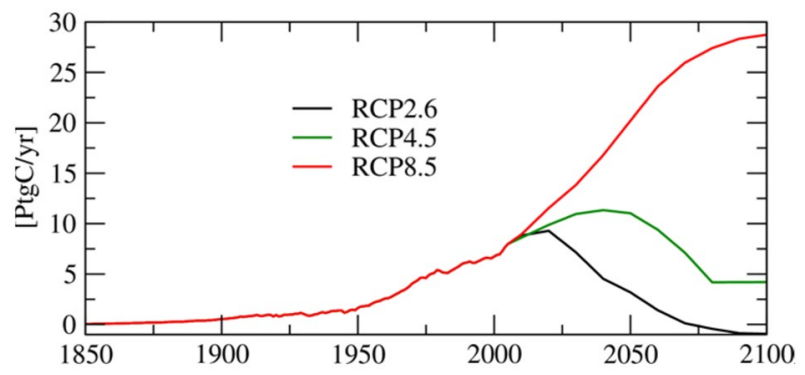

Fig. 1 Carbon emissions from fossil fuels. Emission data were derived from the Potsdam Institute for climate impact research (Meinshausen et al. 2011; https://www.pik-potsdam.de/ mmalte/rcps/) technologies and to the deployment of carbon capture and geologic storage technology (Clarke et al. 2007; Thomson et al. 2011). Emissions decline after 2040 and stabilize after 2080 at a value half of the emissions at the end of the historical period in 2005.

RCP8.5 is developed as a totally unmitigated scenario (Riahi et al. 2007, 2011) in which emissions culminate at a value three times the present value (Fig. 1). It has been criticized in recent years for the assumption of continued usage of coal (e.g. Ritchie and Dowlatabadi 2017a, b). RCP8.5 should be considered with caution rather that a taken as a likely scenario.

Many studies are available that investigated climate change within the Euro-CORDEX region. Some studies concentrate on RCP4.5 and RCP8.5 (e.g. Jacob et al. 2014; Ouzeau et al. 2016; Cardoso et al. 2016; Colmet-Daage et al. 2018). However, inspired by the Paris agreement within the United Nations Framework Convention on Climate Change to limit global warming to $2^{\circ}$ or even to $1.5^{\circ}$, studies have been undertaken to asses the climate change impact for periods when the global mean temperature has increased by these target values in the higher emission RCPs. The advantage of this approach is that such an analysis can be easily carried out on existing RCP4.5 and RCP8.5 simulations without the need to explicitly run additional RCP2.6 scenarios. This has been done so far for global climate climate simulations (e.g. Fischer and Knutti 2015; Schleussner et al. 2016; Mitchel et al. 2016) as well as for regional climate impact studies (Vautard et al. 2014; King and Karoly 2017; Kjellström et al. 2018; Jacob et al. 2018; Teichmann et al. 2018; Jacob et al. 2018). This approach assumes that the regional response to the global warming targets scales proportional across the different pathways of radiative forcing that led to the increase in global temperature. This implies that the regional warming at an e.g. $2^{\circ}$ global warming would be consistent in RCP2.6, RCP4.5, and RCP8.5. Indeed, this assumption has been demonstrated at least for the European sector (Christensen et al. 2019; Matte et al. 2019) and within CMIP5 global models the error produced by this method is much smaller than the model spread (Herger et al. 2015).

However, this approach makes it difficult to assess the direct effect of allowed greenhouse gas emissions which are in practice easier to manage than the global mean temperature. Therefore, in this study the effect of vigorous mitigation is primarily assessed by studying the climate change impact in a range of different greenhouse gas scenarios. Consequently, this study assesses the effect of climate mitigation actions by comparing the climate change response among the RCP2.6, RCP4.5, and RCP8.5 concentration scenarios. 


\subsection{Purpose of the present study}

Past trends in dynamical downscaling made use of declining computational costs and resulted in increasing model resolution and longer integration time scales. In the future these trends will lead to more realistic convection permitting models and will allow ensemble simulations at the centennial scale (Lake et al. 2017; Giorgi 2019; Jacob et al. 2020). With longer time scales to be addressed the greater uncertainty is associated with the slower components of the climate system such as the ocean which comprises a large part of the Euro-CORDEX domain. This gives impetus to the development of coupled atmosphere ocean-models which replace the prescribed ocean surface (mainly sea surface temperatures (SST) and sea ice) by high resolution ocean General Circulation Models (GCMs). Jacob et al. (2020) emphasized the impact of coupling processes among the current challenges for regional climate research within Euro-CORDEX. The authors focused primarily on the importance of atmosphere-land coupling effects (e.g. Dirmeyer et al. 2014; Rahman et al. 2015; Knist et al. 2017) which in Europe are mainly subject to land use management (Davin et al. 2020) rather than the influence of climate as this is the case in less dense populated regions (Wu et al. 2016). Thus, the present study can be considered an extension to the challenge "Impacts of coupled processes and land-atmosphere feedbacks in a regional context" (Jacob et al. 2020) as coupled atmosphere-ocean a feedbacks are focused. Thus, the aim of the this study is to provide a coupled atmosphere-ocean RCM to downscale a multi global model-multi scenario ensemble to asses the climate change at the end of the twenty-first century. The main purpose is to identify the region where interactive coupling is important and how far temperature anomalies simulated by the ocean model translate over the continents at the end of the century.

The use of coupled atmosphere-ocean models in regional climate change studies for the Euro-CORDEX region is still rare (Sein et al. 2020). So far, most studies applied coupled models for the present day climate forced by reanalysis data sets. A number of hindcast studies have documented significant improvements of coupled models compared to uncoupled models (e.g., Tian et al. 2013; van Pham et al. 2014; Sein et al. 2015; Gröger et al. 2015; Ho-Hagemann et al. 2017; Primo et al. 2019; Ho-Hagemann et al. 2020; Cabos et al. 2020). With regard to the ocean, early studies focused primarily on short term simulation of a few years (Hagedorn et al. 2000; Döscher et al. 2002; Schrum et al. 2003) up to a few decades (e.g. Döscher et al. 2004). Later studies were able to perform multi-decadal simulations and could investigate long term effects of coupled vs uncoupled models (e.g. Meier et al. 2011, 2012). Tian et al. (2013) and Gröger et al. (2015) demonstrated a significant improvement of winter SSTs in the Baltic Sea by using coupled models compared to ocean standalone models.

In contrast to the ocean which is fully overlain by the atmosphere, open waters constitute only a part of the atmospheric boundary layer implying that the added value of coupling is also dependent on the land - sea area ratio in the model domain. However, as many hazardous weather phenomena like flooding, storms, extreme precipitation originates from open sea areas, a well represented SST is essential. Thus many studies for the present day climate investigated the added value of coupling on the representation of short term events. Jeworrek et al. (2017) could show that a better SST representation in the coupled climate model RCA4-NEMO compared to prescribed ERA40 SSTs improved the representation of convective snow bands. HoHagemann et al. (2017) compared coupled and uncoupled runs of different models to investigate the weather regimes associated with major floodings in central and eastern Europe. Akthar et al. (2017), investigated coupling effects on $\mathrm{Vb}$ cyclones in a model set up for the Euro-CORDEX region coupled to regional ocean models for the Mediterranean, the North Sea and the Baltic Sea and found a good representation of cyclones in both coupled and uncoupled simulations. Using a similar set up Primo et al. (2019) demonstrated a better representation of extreme temperatures in coupled runs for the twentieth century compared to uncoupled runs. Kelemen et al. (2019) showed significant effects on European continental precipitation in twentieth century simulations by driving the model in coupled mode and by prescribed passive SST fields. More recently, climate studies for the Mediterranean region (Med-CORDEX) were carried out with coupled regional atmosphere-ocean models (e.g. Gaertner et al. 2018; Damaraki et al. 2019; Soto-Navarro et al. 2020).

The above mentioned studies documented important coupling effects in simulations for the present day climate. Thus, the question arises whether these effects could significantly alter the climate change response in future climate scenarios. Evidence for that can be found in Kjellström et al. (2005) who compared 30-years time slice simulations for the end of the twentieth and twenty-first century and found significant differences between a coupled and uncoupled model in summer precipitation mediated by certain weather regimes. More recent climate studies for the Mediterranean region (Med-CORDEX) were carried out with coupled regional atmosphere-ocean models (Damaraki et al. 2019; Soto-Navarro et al. 2020). However, a systematic assessment on how the response to climate change at the end of the twenty-first century will differ between coupled and uncoupled models is to our knowledge still not available.

Recent climate change assessments by the Euro-Codex initiative are based on a huge ensemble of uncoupled atmosphere models of $50 \mathrm{up}$ to $12.5 \mathrm{~km}$ resolution (e.g. 
Jacob et al. 2014; Kjellström et al. 2018; Rajczak and Schär 2017). Thus one goal of our study is to present an ensemble of coupled atmosphere-ocean climate change and to identify regions where coupling can be considered important. For this, we compare our results with assessments of previous studies relying on uncoupled models. In addition to that we directly compare coupled and uncoupled simulations for the present day climate.

We here present a relatively large ensemble of transient scenario simulations with a regional, coupled atmosphere-ocean model driven by 9 GCMs and 3 RCPs. Hence, we will analyze seasonal mean climate change as well as selected climate indices for extremes with focus on air sea feedback mechanisms that are realistically represented in coupled ocean-atmosphere models. Compared to the high resolution Euro-CORDEX ensemble provided by Jacob et al. (2014), our ensemble is limited by nine global models and one single regional climate model. Furthermore, the coupled area consisting of the North Sea Baltic Sea is only part of open water areas in the Euro-CORDEX domain. However, coupled simulations are more expensive than atmosphere only simulations. That is also the reason why our ensemble is based on $24 \mathrm{~km}$ resolution compared to $12.5 \mathrm{~km}$ in the ensemble used in Jacob et al. (2014). Thus, this study should be understood as first step to elaborate the role of coupling in regional future climate change scenarios.

\section{Methods}

\subsection{Cimate indices}

A number of attempts have been undertaken to develop general climate indices to characterize mean and extreme climate (e.g. Karl et al. 1999; Peterson et al. 2001; Peterson 2005). Beyond this numerous indices exist with specific usage in e.g. farming, wind energy etc. In an attempt to harmonize the usage of climate indices the European Climate Assessment and Dataset (ECA\&D) group has compiled a list of indices for various purposes (available at https://www.ecad.eu//documents/atbd.pdf). We here calculated five indices with regard to purposes explained below.

\subsubsection{Tropical nights}

The definition of tropical nights follows here the common approach and defines tropical night as days where the minimum temperature does not fall below $20^{\circ} \mathrm{C}$ (e.g. Fischer and Schär 2010; Teichmann et al. 2018; Meier et al. 2019).

\subsubsection{Heat waves}

The majority of studies analyzing heat waves uses spatially varying thresholds such as the number of $>5$-day periods where the temperature exceeds the e.g. 95th percentile of a reference period (e.g. Jacob et al. 2014) or where daily maximum temperature exceeds the mean May to September maximum temperature of the reference climate (Frich et al. 2002; Vautard et al. 2013; Jacob et al. 2014). This approach is well suited to describe the change in climate extremes specific for a certain locality. However, it is less well suited for estimating the potential impact on human health which presumably is more sensitive to absolute high temperatures rather than the (positive) anomaly to the mean local climate although we are aware that people used to warmer climates may be more robust to high temperatures than people living in cooler regions. Consequently, we define hot waves as periods with $>5$ consecutive days where the maximum temperature exceeds a certain temperature. The threshold is chosen to be $30{ }^{\circ} \mathrm{C}$ following Teichmann et al. (2018).

\subsubsection{Frost days and Ice days}

There is growing evidence that milder winters promote the occurrence of plant pests and tree diseases (e.g. Pureswaran et al. 2018) as the overwintering of insects in the absence of cold spells is easier. In particular, frost and ice has been assumed to lower the survival of insect eggs and larvae (e.g. Pureswaran et al. 2018). Thus, frost and ice days are defined here as days where the minimum daily temperature falls below $0{ }^{\circ} \mathrm{C}$ (frost days) or where the maximum daily temperature remains below $0{ }^{\circ} \mathrm{C}$.

\subsubsection{Dry spells}

Dry spells are defined in an analog way as hot spells, i.e. periods of $>5$ consecutive dry days (= days with $<1 \mathrm{~mm} /$ day, e.g. Jacob et al. 2014).

\subsubsection{Bias adjustment}

Climate indices that are based on absolute threshold values are extremely sensitive to systematic model biases. For example, a significant warm (cold) temperature bias would result into too high (too low) amounts of tropical nights for which the threshold is $20{ }^{\circ} \mathrm{C}$ minimum daily temperature. Therefore, a bias adjustment on the model data has been carried before calculation of the respective climate index. We here applied the delta method. Thus, monthly mean difference fields between EOBS data and the model output were calculated and then used to correct the daily fields of temperature and precipitation. Details of this method are described in (Teutschbein and Seibert 2012; Mathis et al. 
2013). We note that bias adjustment was done only over land since the reference EOBS data set contains no values over open ocean areas.

\subsection{Regional climate model and climate ensemble}

For our investigation we use a high resolution climate ensemble produced by a coupled regional atmosphere ocean model (Regional Climate Model, RCM, Wang et al. 2015; Dieterich et al. 2019a) for Europe and the Baltic Sea and the North Sea.

The RCM version used in this study is the coupled regional atmosphere-ocean model RCA4-NEMO3.3.1. It differs from the majority of CORDEX models by including an interactively coupled high resolution regional ocean general circulation model. Thus, sea surface temperature and sea ice cover are updated every $6 \mathrm{~h}$ by the changes simulated by the 3D ocean model. The ocean model is based on the Nucleus for European Modelling the Ocean, (NEMO and Madec 2012) which is setup for the North Sea and Baltic Sea (Gröger et al. 2015, 2019; Dieterich et al. 2019a). NEMO is set up with horizontal resolution of $\sim 3.7 \mathrm{~km}$ and the water column is divided by 56 irregular positioned z-layers yielding a layer thickness of $3 \mathrm{~m}$ near the surface and up to $22 \mathrm{~m}$ in the deepest layers. The ocean is updated every 6-h with forcing fluxes provided by the atmosphere model. Details for the coupling of the models are provided by Wang et al. (2015), Gröger et al. (2015), and Dieterich et al. (2019a). A detailed and comprehensive description of the ocean model can be found in Dieterich et al. (2019a). The atmosphere model is the Rossby Center Atmosphere model (Samuelsson et al. 2011; Wang et al. 2015) which is setup for the EUROCORDEXCORDEX domain with a horizontal resolution of $0.22^{\circ}$ and 40 level vertical level. The model has been comprehensively described along with a profound validation of the simulated mean present-day climate by Wang et al. (2015) and Dieterich et al. (2019a).

For the present study the model has been applied to downscale a suite of different global climate scenarios from the 5th phase of CMIP (Table 1). For this, both the atmosphere as well as the ocean model was driven at the lateral boundaries by prescribed outputs fields from the global climate models. Surface boundary fields for the atmosphere model outside the coupled domain (i.e. the Atlantic Ocean, Black Sea, Arctic, and the Mediterranean Sea) were taken from the respective global climate model.

The model simulations comprise the historical period from 1961 to 2005 and three scenario for the period 2006-2099. Each of the ensemble members provides a huge amount of four dimensional climate data containing much of internal unforced variability as well as uncertainty with respect to the chosen model and scenario (Table 1). Analysis is concentrated on 30-years periods for the historical
Table 1 Matrix of downscaled global climate change simulations for different greenhouse gas concentration scenarios

\begin{tabular}{lllll}
\hline & $\begin{array}{l}\text { Hindcast/ } \\
\text { historical }\end{array}$ & RCP2.6 & RCP4.5 & RCP8.5 \\
\hline ERA40 (uncoupled) & $\mathrm{x}$ & & & \\
ERA40 & $\mathrm{x}$ & & & \\
MPI-ESM-LR & $\mathrm{x}$ & $\mathrm{x}$ & $\mathrm{x}$ & $\mathrm{x}$ \\
EC-EARTH & $\mathrm{x}$ & $\mathrm{x}$ & $\mathrm{x}$ & $\mathrm{x}$ \\
HadGEM2-ES & $\mathrm{x}$ & $\mathrm{x}$ & $\mathrm{x}$ & $\mathrm{x}$ \\
IPSL-CM5A-MR & $\mathrm{x}$ & & $\mathrm{x}$ & $\mathrm{x}$ \\
GFDL-ESM2M & $\mathrm{x}$ & $\mathrm{x}$ & $\mathrm{x}$ & $\mathrm{x}$ \\
CanESM2 & $\mathrm{x}$ & & $\mathrm{x}$ & $\mathrm{x}$ \\
CNRM-CM5 & $\mathrm{x}$ & & $\mathrm{x}$ & $\mathrm{x}$ \\
NorESM1-M & $\mathrm{x}$ & $\mathrm{x}$ & $\mathrm{x}$ & $\mathrm{x}$ \\
MIROC5 & $\mathrm{x}$ & $\mathrm{x}$ & $\mathrm{x}$ & $\mathrm{x}$ \\
\hline
\end{tabular}

climate 1970-1999 and at the end of te century 2070-2099 to account for short term variabilty. Where appropriate we test the significance of results to distinguish stochastic forcing from the forced climate signal and test the robustness of results. The latter is tested following Jacob et al. (2014) by defining robustness when the climate change signal is in qualitative agreement in at least $2 / 3$ members of the whole ensemble ( $=9$ model members, Table 1$)$. Results in areas that do not fulfill this demand are masked out in plots displaying the ensemble mean. All other areas represent the ensemble mean over the whole model ensemble. Significance for individual model simulations is tested by a signal to noise test. The noise is generated using bootstrap approach that randomly re-samples in total one hundred 30-years climate periods.

\section{Validation of present day climate}

The coupled ocean-sea ice-atmosphere model RCA4-NEMO is a recently developed RCM that has been validated comprehensively in a number of previous papers for the mean climate of the historical period. A comprehensive comparison with different existing observational, and reanalysis data sets has been given in Dieterich et al. (2019a) for both atmospheric, and oceanographic prognostic variables for the North Sea. Gröger et al. (2019) compared simulated water mass properties with focus on the Baltic Sea and North Sea using the satellite products from the Federal Maritime and Hydrographic Agency, Hamburg, Germany as well as in situ measurements for water temperature and salinity from the KLIWAS data set (Bersch et al. 2013) and from the Swedish Ocean Data Archive (SHARK, https://sharkweb.smhi. se/). Wang et al. (2015) compared the simulated atmosphere climate with observational data sets from Climate Research 
Unit (CRU) TS3.21 data (Harris et al. 2014). These previous studies used different atmospheric reanalysis data sets to force the model at the lateral boundaries for the historical period from 1961 onward. The main findings of the studies were that the simulated mean climate state was well within the uncertainty range of available observations and that the model can be used well to downscale future climate change scenarios from global climate and earth system models.

Apart from the model's ability to represent the mean present day climate state, several studies provide validations for the models skill to reproduce certain extreme climate phenomena such as convective snowbands (Jeworrek et al. 2017), extreme precipitation events (Ho-Hagemann et al. 2017), storm track intensity (Gröger et al. 2015), and extreme sea levels in the Baltic Sea (Dieterich et al. 2019b).

In this paper we primarily refer to the studies by Wang et al. (2015) and Dieterich et al. (2019a) who provide a comprehensive and quantitative validation with special focus on atmospheric variables on longer time scales. Therefore, in this study we concentrate on the models ability to reproduce mean seasonal and anomalous climatic conditions important for this study. We do not intend to produce semi-quantitative skills scores (these can be assessed from the aforementioned studies) but lay emphasis on the models ability to realistically represent spatial patterns as well as the ability to reproduce inter-annual variability which is important for the purpose of this study. Accordingly, rather than using observational real time station data to compare the model with, we here apply the spatially gridded E-OBS data set which is constructed upon a 100 member ensemble based on interpolated station data (for details see Cornes et al. 2018). An important driver of the wintertime interannual variability is given by the North Atlantic Oscillation (NAO). Due to it's limited domain the large scale circulation over the whole North Atlantic can not fully represented by the regional climate model. Therefore, the driving GCMs ability to represent the NAO is important. However, Wang et al. (2017) have shown, that at least the basic NAO characteristics are represented reasonably well in 40 CMIP5 global models.

For the comparison, climate indices are calculated from the model output and compared to those derived in the same way from the E-OBS gridded data set. For the validation we follow the general guideline of EURO-Cordex as outlined by Kotlarski et al. (2014). Hence, for the validation the coupled model has been forced by atmospheric hindcast data derived from the ERA40 reanalysis data set in order to ensure that the large scale atmospheric forcing prescribed at the lateral boundaries is in phase with real climate. In this mode the model can be expected to reproduce interannual variability. By contrast, when driven by output fields from global climate model scenarios even the models lower frequency fluctuations (like e.g. decadal variability) must be expected out of phase with the recorded climate, because global coupled climate models generate their own weather. Therefore, in the climate mode the model will only reproduce the long term (i.e. 30 years) mean climate and variability which is focused in this study. Thus, in addition to the hindcast run we test the models ability to preserve predictive skills when driven by global model climate output. For this, an ensemble mean over the nine downscaled global models is calculated for every climate index and compared to the corresponding index from the hindcast run and the E-OBS data set. In the first part of this section we test the models ability to reproduce the mean seasonal climate state. In the second part we calculate climate indices reflecting extraordinary conditions and compare model results with the indices calculated from the E-OBS.

\subsection{Simulation of mean seasonal climate}

\subsubsection{Air temperature}

Figure 2 shows the simulated winter and summer $2 \mathrm{~m}$ air temperature for the ERA40 hindcast run and for the ensemble mean climate runs with E-OBS data. During winter (Fig. 2a) the spatial pattern is well reproduced in both the hindcast simulation and the ensemble mean of historical climate simulations. This is especially true for central Europe while over Scandinavia and northern Russia slightly too low temperatures are simulated by the model. The effect of fast cooling land masses compared to the open ocean builds up a clear land see contrast in which lowest temperatures occur over northeast Europe while highest temperatures are seen in southwest Europe where the influence of warmer Atlantic waters masses advected from subtropical regions is notable. This is also reflected in the temperature contrast between the North Sea and the Baltic Sea west and east of Scandinavia. The North Sea reflects temperatures similar to the Atlantic sector due to vigorous inflow of warm water masses that release heat to the atmosphere during the cold season. By contrast, the Baltic Sea as a marginal sea has restricted exchange with open ocean waters and a strong permanent halocline reduces the effective heat capacity. As a result the upper Baltic cools faster during winter and thus air temperatures are similar to the surrounding land masses. This contrast vanishes during summer when the open water masses of the Atlantic and the North Sea undergo a strong thermal stratification and a sharp thermocline develops. As a result air temperatures are dominated by the large scale atmospheric conditions with no pronounced land-sea contrast in the climatological mean (Fig. 2b). Despite the well representation of the spatial pattern which implies that the local processes determining $\mathrm{T} 2 \mathrm{~m}$ are considered for, the model is generally too cold both during winter and summer with the exception of the easternmost regions where the model is too warm (see also Suppl. Mat. S1). This warm 
a EOBS

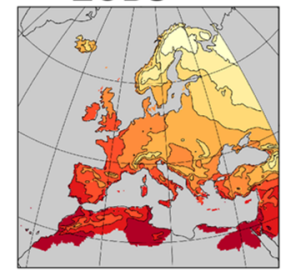

ERA40-driven
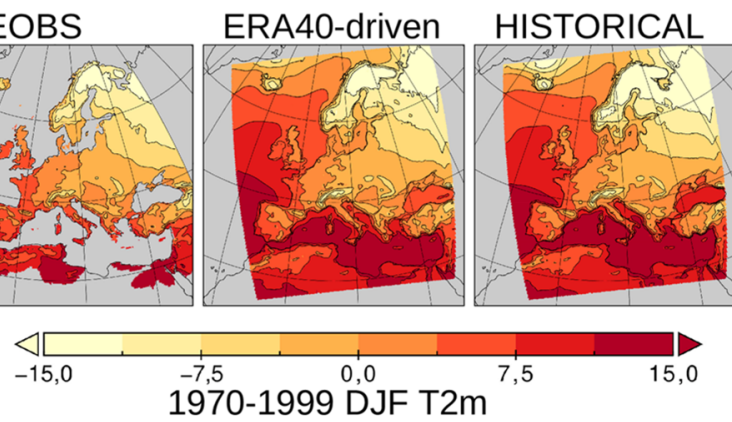

b EOBS

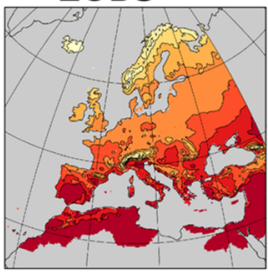

ERA40-driven
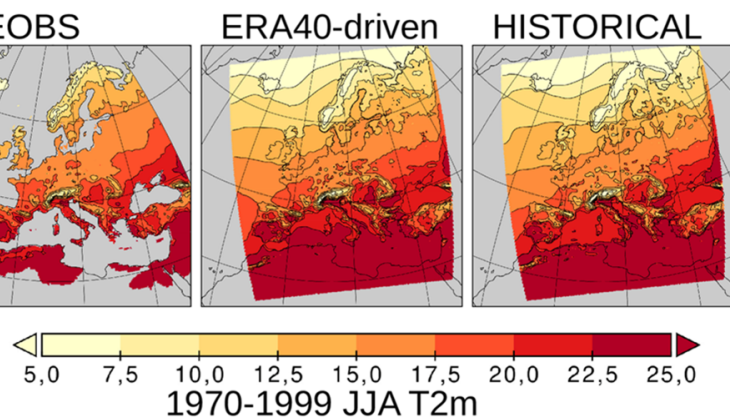

C

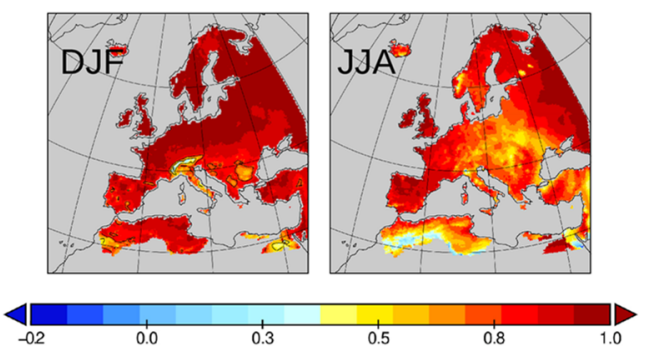

Fig. 2 a Comparison of $2 \mathrm{~m}$ air winter temperature between E-OBS data set (left), the ERA40 coupled hindcast run (middle), and the climate models' ensemble mean (right). b Same as (a) but displaying summer temperature. c Correlation between the E-OBS data set and the ER40 hindcast run for the winter season (left) and summer season (right)

bias is also seen in the ERA40 hindcast simulation which is reduced in the historical ensemble mean (Suppl. Mat. S1b).

An essential requirement for climate applications is the models ability to capture interannual variability as it tells about the models ability to realistically respond to changes in the meteorological forcing which will be the main impact to be expected under a changed climate. Figure $2 \mathrm{c}$ shows the spatial distribution of correlation coefficients between the E-OBS data set and the hindcast run. High coefficients are seen for winter temperatures with values almost everywhere above 0.8 . This indicates that inter-annual changes in winter time large scale circulation (as controlled by e.g. the NAO) are quite well covered by the model. Likewise good correlation is seen during summer although locally coefficients can drop to $\sim 0.5$ like in larger areas of Poland and the Balkans.
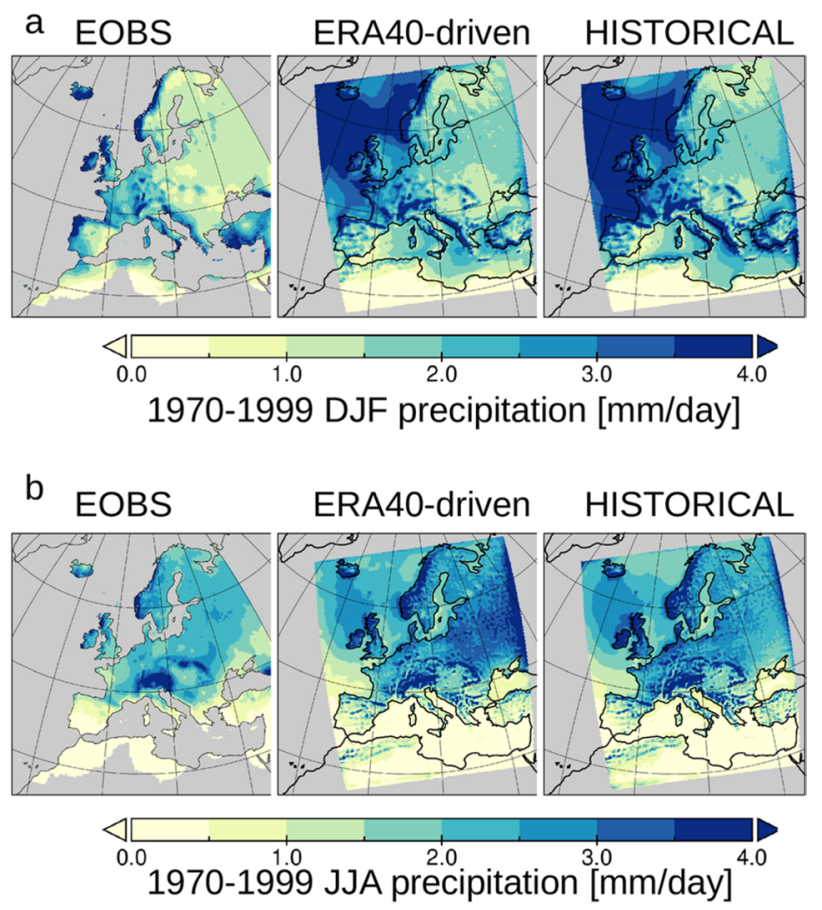

C

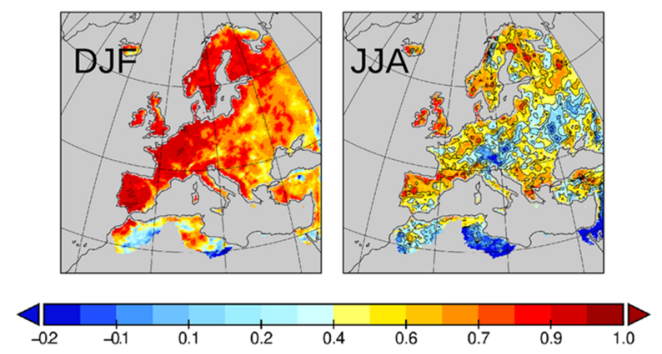

Fig. 3 a Comparison of mean daily precipitation rates (mm/day) during winter between E-OBS data set (left), the ERA40 coupled hindcast run (middle), and the climate models ensemble mean (right). b Same as (a) but displaying summer precipitation. c Correlation between the E-OBS data set and the ER40 hindcast run for the winter season (left) and summer season (right)

The slightly lower summer coefficients compared to winter are expected as in winter temperatures are controlled more by the atmospheric large scale circulation patterns like e.g. the core path of westerlies while during summer small scale processes (such as local convective rain cells) as well as stochastic forcing are of greater importance for the local climate.

\subsubsection{Precipitation}

Figure $3 \mathrm{a}, \mathrm{b}$ compare the multi-year seasonal precipitation pattern for winter and summer. In the two seasons precipitation rates are mostly overestimated. For winter both the ERA40 hindcast and the historical ensemble mean yield positive deviations to the E-OBS data set between 1 and $2 \mathrm{~mm} /$ 
day on average (Suppl. Mat. S2). During summer the especially the ERA40 hindcast yields to high precipitation rates (Suppl. Mat. S2b). This bias is fairly reduced in the models historical ensemble mean. However, the large scale spatial pattern of the E-OBS data set is well reproduced in both the hindcast run and ensemble mean of climate simulations. Winter precipitation rates highly related to the prevalent westward wind regime. Thus, maximal precipitation rates are seen along western European coasts and decline rapidly towards the inner continental areas. This is well observed along the coasts of Iberia, the UK, Norway, along the Adriatic coast, as well along the Greek and western Turkish coast (Fig. 3a). The imprint of the Icelandic Low pressure system is indicated by high precipitation rates south of Iceland and in vast areas of the NE Atlantic. During summer, precipitation rates are larger compared to winter over most of the European continent in both the E-OBS data sets and in the simulations. Maximal precipitation rates are concentrated around orographic barriers likes the Alps, Carpathians or along the orogenic belt of Norway.

During the winter season, interannual variability is quite well reproduced (Fig. 3c left). This is probably related to a well representation of large scale pattern like the NAO forced mean surface temperature variations or Atlantic Overturning Circulation (AMO) in global models (Wang et al. 2017).

Although the general spatial pattern of precipitation is likewise covered well during summer, this does not translate into high correlation coefficients for interannual variability (Fig. 3c, right). This problem has been recognized in earlier studies and has been described as "double penalty problem" (e.g. Prein et al. 2013). According to this, the position of small scale convective rain cells, as they can build up frequently during summer and forced by stochastic processes, can not be exactly represented in models in space and time. Therefore, local correlation coefficients are not a good approach to judge model performance especially for climate applications. Moreover, convective rain cells have been even recognized a problem in the E-OBS data set as both, root mean squared errors and mean absolute errors are quite larger in summer than in winter (Cornes et al. 2018). Advanced methods of data pre-processing were developed to overcome this problem (e.g. Prein et al. 2013). However, as in this study the focus is on the analysis of global climate scenarios which in any case produce their own weather, an exact match between model results and observations would in any case not be possible. However, if we correlate averages over larger areas that smooth out small scale precipitation events like e.g. for Europe (between $5^{\circ} \mathrm{W}$ and $30 \mathrm{E}$; $45-65^{\circ} \mathrm{N}$ ) the correlation coefficients spread around 0.7 indicating that interannual variations of large scale atmospheric moisture transports and precipitation are covered well. Thus, following earlier regional climate studies (Jacob et al. 2014; Kjellström et al. 2018) we consider the models precipitation sufficiently good for climate change studies not intending to exactly resolve stochastically forced variability.

\subsection{Climate indices depicted from the historical period}

In the following we calculate climate indices calculated from the models output variables which later will be used to display the climate change signal in the models' climate ensemble.

Figure 4a displays the number of hot spells for summer sampled during the 1970-1999 reference period as found in the E-OBS data set, the ERA40 hindcast run, and the models climate ensemble mean. As expected the general pattern is mainly controlled by topography and latitude. In the UK, Scandinavia, and the northernmost part of Russia hot spells occur only sporadically or are completely absent. Most hot spells occur in the subtropics in northern Africa but are also frequent in the southern part of Iberia. In these southern regions hot spell are slightly overestimated in both the hindcast run as well as the historical ensemble mean. Over the open ocean hot spells are absent due to the heat loss to the sea. Only in the ensemble mean these periods can sporadically occur in the eastern Mediterranean near coastal
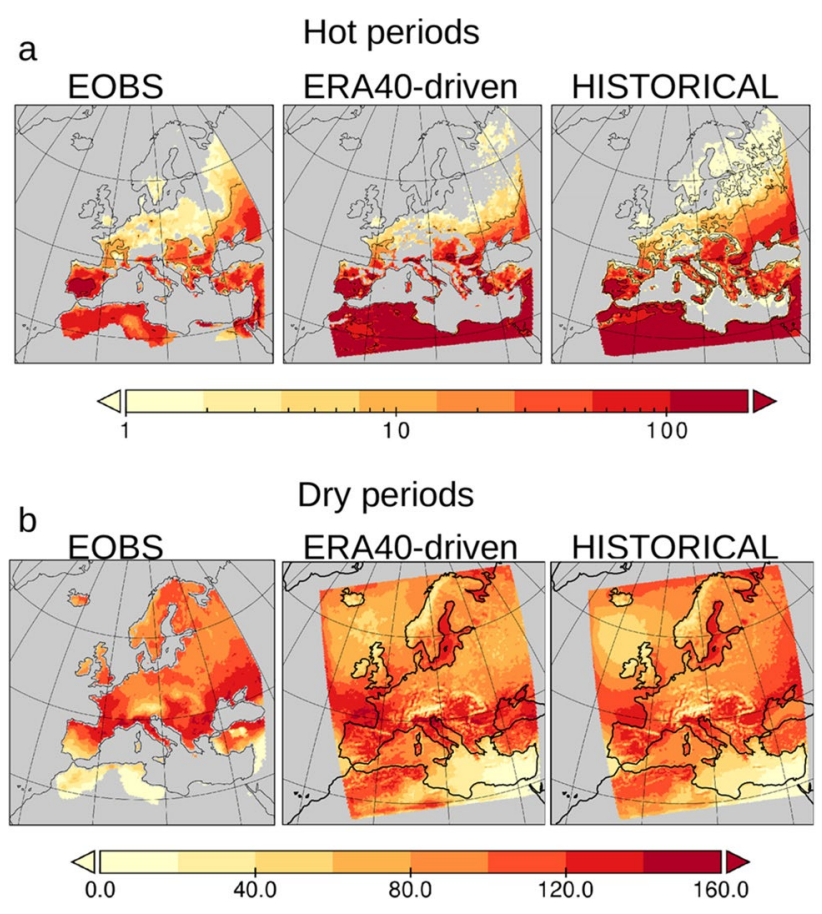

Fig. 4 a Number of summer hot spells defined as at least 5 consecutive days where the maximum temperature exceeds $30{ }^{\circ} \mathrm{C}$ derived from E-OBS, the coupled hindcast run, and the models climate ensemble mean. b Same as (a) but for at least 5 days where precipitation is below $1 \mathrm{~mm} /$ day. Note the E-OBS data provide no data over the sea 
areas where the surface water can reach temperatures close to $30^{\circ} \mathrm{C}$.

In the European sector dry periods (Fig. 4b) occur most frequently in a zonal band around northern Spain/southwestern France, Italy, Greece, and around the Black Sea. In semi-arid regions like northern Africa the total number of dry periods is limited by persistent droughts that can prevail over the whole summer. This effect is also seen over the southern part of Spain and Portugal. As already shown by the hot spells, also dry periods are affected by orogenic barriers which cause uplift of warmer air masses as indicated by the rare occurrences around Carpathian Mountains, the Alps, and over Norway. These orogenic imprints are more pronounced in the model simulations than in the E-OBS data set. In general, we can conclude that the model compares well with E-OBS in both the diagnosed hot and dry periods.

\subsubsection{Tropical nights and yearly maximum temperature}

Tropical nights are defined as days where the daily minimum temperature does not fall below $20^{\circ} \mathrm{C}$. As expected, these nights are most frequent over the Mediterranean Sea and northern Africa. In the temperated European continental regions tropical nights occur more or less sporadically (Fig. 5a). Regular occurrences of every to every second year are only seen in southeastern Europe, north of the Black Sea and over Iberia. This is slightly underestimated in the model

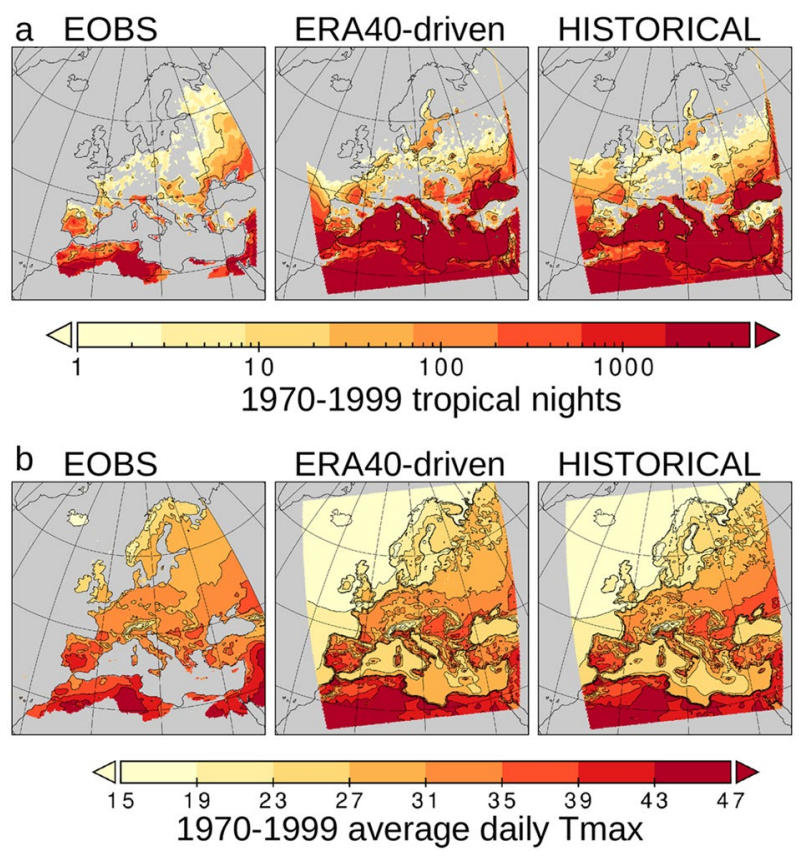

Fig. 5 a Number of tropical nights defined as days where the minimum temperature does not fall below $20^{\circ} \mathrm{C}$. b Average yearly maximum $2 \mathrm{~m}$ air temperature $\left[{ }^{\circ} \mathrm{C}\right]$. Note that the E-OBS data set lacks data over open water runs. In the subtropics south of the Mediterranean land masses heat up strongly over the day to keep the temperature over $20^{\circ} \mathrm{C}$ during night. In the temperated regions north of the Mediterranean local water bodies with high effective heat capacity compared to land control the distribution of tropical nights. This can be seen especially over the Black Sea but also over the Baltic Sea and the North Sea where maximum water temperatures rarely rise above $\sim 27{ }^{\circ} \mathrm{C}$ (Fig. 5b) but which nevertheless represent local hot spots of tropical night occurrences compared to the surrounding land masses (Fig. 5a).

The spatial pattern of yearly maximum $\mathrm{T} 2 \mathrm{~m}$ shows a clear land-sea pattern locally modulated by topography (Fig. 5b). By contrast, no land-sea pattern is seen in the when considering the $95^{\text {th }}$ percentile temperature (Fig. 6a). This indicates that for temperatures right below the yearly maximum, the contrasting land-sea heat capacity is of only minor importance in controlling the spatial temperature pattern. Instead the pattern of the 95th percentile (Fig. 6a) resembles that of the mean summer temperature seen in Fig. $2 b$ indicating greater influence of the mean Fig. 2b) the 95th percentile temperature is a bit too cold compared to the E-OBS data set especially in northern Europe while the spatial pattern is quite well resolved (Fig. 6a). The same true for the 25th percentile of winter temperatures (Fig. 6a). During the cold season strong gradients are build up between extremely cold and dry air masses around Fennoscandia and northern
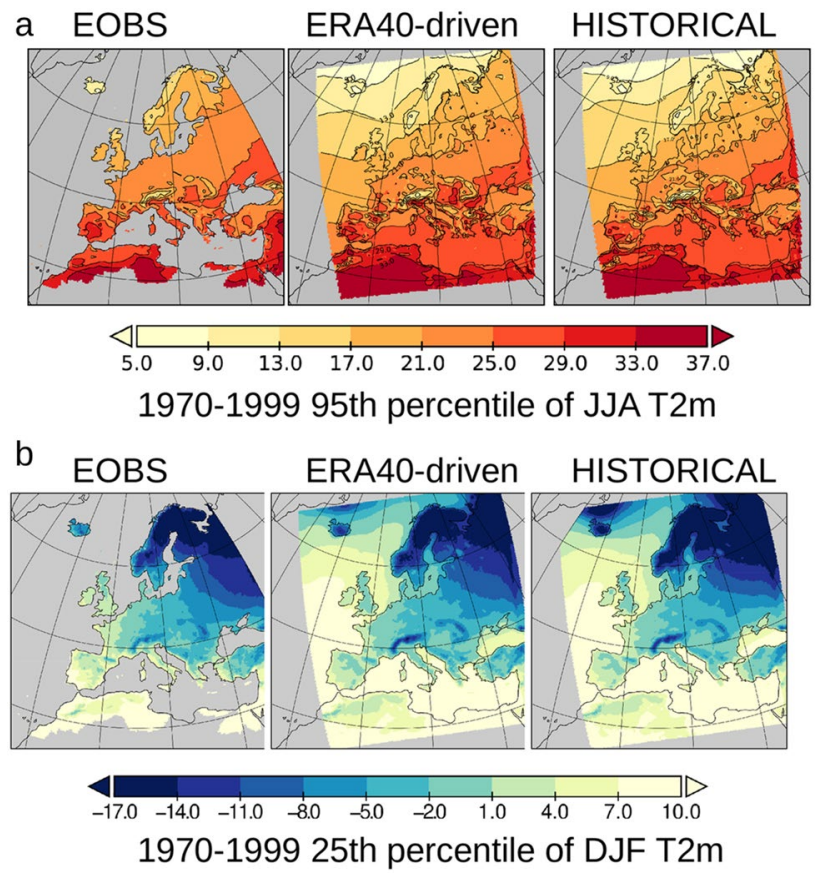

Fig. 6 a 95th percentile of summer $2 \mathrm{~m}$ air temperature calculated from the E-OBS data set, the coupled ERA40 hindcast run, and the climate scenario ensemble. b Same as (a) but displaying the 25th percentile of winter $2 \mathrm{~m}$ air temperature 
Russia in the northeast, and the warm water pool of the Atlantic acting as a heat source. Furthermore, a clear landsea pattern is seen indicating the slow response of the ocean to the meteorological forcing compared to the land masses (Fig. 6b).

\section{Climate change analysis}

\subsection{Mean seasonal climate change}

Figure 7 shows the T2m for the model simulations following the three climate scenarios. In addition to the ensemble members, the T2m calculated from the E-OBS data set and the ERA40 hindcast run is indicated as thick black and red lines in the lowest panel of Fig. 7 respectively. Over the historical period and further up to 2018 the ensemble members spread around the observation based estimates for both summer and winter. This indicates that the ensemble mean can be considered a good approximation for the long term real mean climate state despite that fact that some of the members are outside the internal variability of the E-OBS data set. Moreover, correlation between the ERA40 hindcast run (thick red line) and the E-OBS data set (thick black line) reveals coefficients of $r=0.88$ (winter) and $r=0.79$ (summer) which indicates a good reproduction of interannual variability.

In the high concentration RCP8.5 scenarios the warming trend is still significant at the end of the twenty-first century in all model realizations and over both land, and open water areas as well as for winter and summer season (Fig. 7, upper panel). This is also the case for open water areas in winter following the RCP4.5 scenarios. In all other simulations independent of the season, the scenario or whether land or ocean areas are considered, the warming trend has already ceased at the end of the century. Besides the fact that the low emission scenario RCP 2.6 shows the by far weakest response this scenario indicates almost an equilibrium state with no significant trends since the mid of the century which is in line with the RCP2.6 pathway of greenhouse gas concentration which peaks around 2040 and slightly decreases afterwards.

In all scenarios the temperature response is substantially higher over land than over the open sea reflecting the slower thermal response to climate warming of the ocean due to its higher effective heat capacity. Over land, depending strongly on the RCP scenario, temperatures rise between $1.93 \mathrm{~K}(\mathrm{RCP} 2.6)$ and $4.76 \mathrm{~K}$ (RCP8.5) averaged over the model ensemble during the winter season and between $1.59 \mathrm{~K}$ and $5.0 \mathrm{~K}$ during summer (Table $2 \mathrm{a}$ ).

\section{DJF}
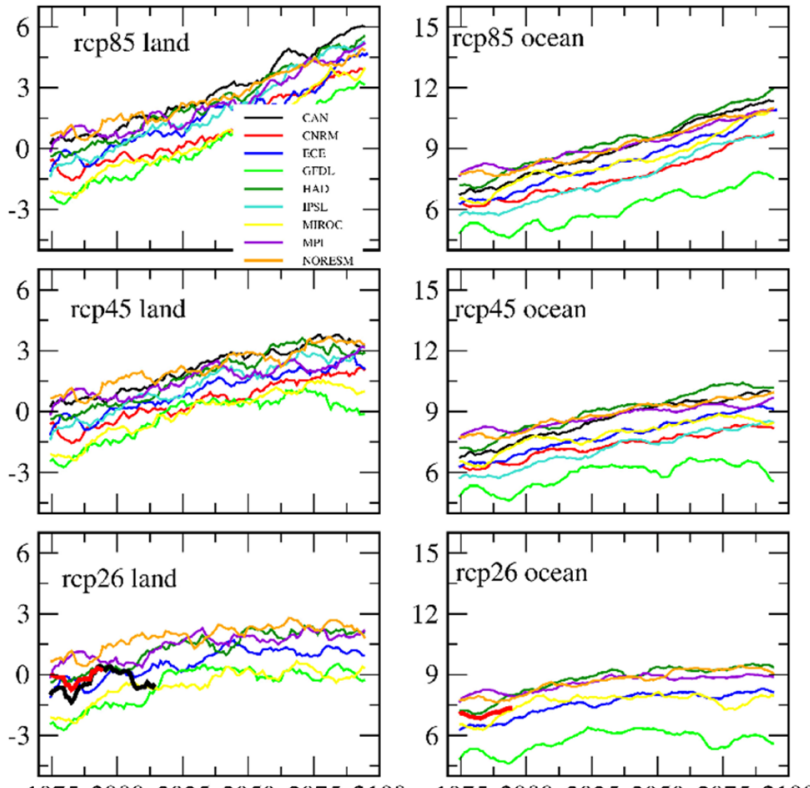

197520002025205020752100
197520002025205020752100
JJA
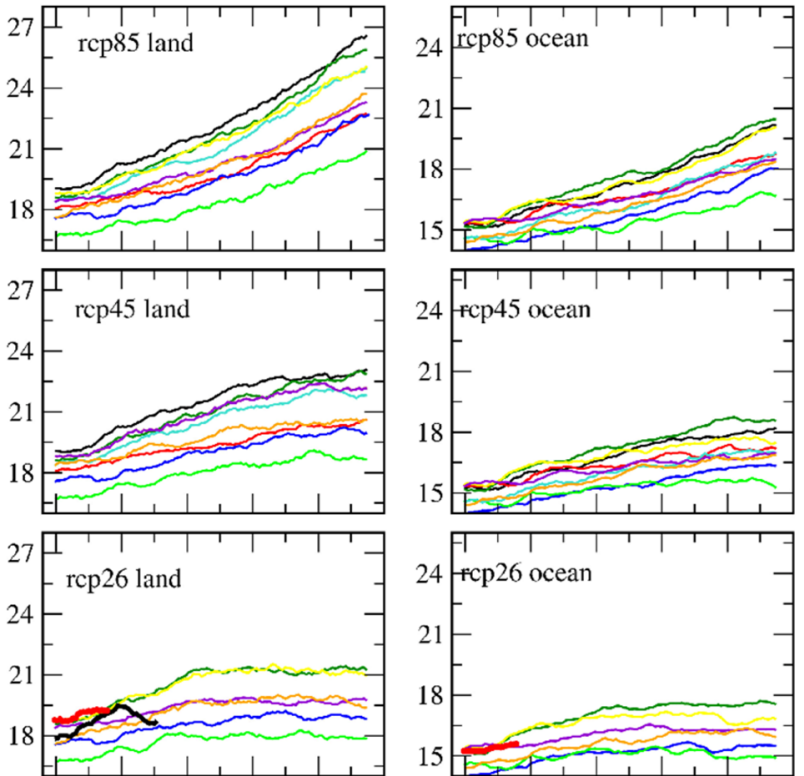

$197520002025205020752100 \quad 197520002025205020752100$
Fig. 7 Time series of area averaged $\mathrm{T} 2 \mathrm{~m}\left[{ }^{\circ} \mathrm{C}\right]$ for winter (DJF) and summer (JJA). Note that all time series are identical for the historical period before 2005. Land and ocean denote areas averaged taking into account land or open sea area only. Corresponding time series from the E-OBS data set have been included in the rcp2.6 plots (lowermost panels) for comparison. Note that the $y$-axis is always equally ranged for ocean and land temperature to facilitate comparison. A 10-years running mean is shown. The thick black and red lines indicate corresponding times series derived from E-OBS data set and from ERA40 hindcast run respectively 
Table 2 (a) T2m difference $\left[{ }^{\circ} \mathrm{K}\right.$ ] between 2070 and $2099-1970$ and 1999 averaged over winter and summer season as well as over land and over sea. (b) Relative [\%] difference in T2m standard deviation between 2070 and 2099-1970-1999 averaged over winter and summer season as well as over land and over sea

\begin{tabular}{lrrrrr}
\hline & \multicolumn{2}{l}{ Winter } & & \multicolumn{2}{l}{ Summer } \\
\cline { 5 - 6 } & Land & Ocean & & Land & Ocean \\
\hline (a) $\Delta$ T2m & & & & \\
RCP8.5 & 4.76 & 3.40 & & 5.00 & 3.43 \\
RCP4.5 & 2.88 & 2.14 & & 2.97 & 2.06 \\
RCP2.6 & 1.93 & 1.26 & & 1.59 & 1.18 \\
(b) $\Delta$ STD [\%] & & & & \\
RCP8.5 & -14.16 & -3.50 & & 62.73 & 36.65 \\
RCP4.5 & -20.27 & -30.40 & & -4.36 & -21.29 \\
RCP2.6 & -19.76 & -26.06 & & -12.80 & -19.58 \\
\hline
\end{tabular}

Over the open sea the atmosphere warms between $1.18 \mathrm{~K}$ (RCP2.6), and 3.40 (RCP8.5) during winter and between $1.8 \mathrm{~K}$ and 3.43 during summer.

Relative changes in inter-annual variability as indicated by the ensemble mean standard deviation is listed in Table 2b. For the winter season a consistent signal of reduced variability by up to $30 \%$ over both land and open sea. Overall, this may indicate a lower amplitude of the North Atlantic Oscillation in the future climate.

Land-sea thermal contrasts during the winter become less pronounced as the temperatures over land masses rises stronger than over the open ocean (Table 2a). This is related to the lower effective heat capacity of land masses compared to the ocean which responses slower to climate warming. Thus, because land masses are generally colder than the ocean in winter, the stronger increase of land temperatures damps the overall land-sea temperature contrast. However, the contrary is true for the summer because the atmosphere is usually warmer than the ocean during the warm season. A faster warming of land masses compared to the ocean therefore increases the land-sea thermal gradients under climate warming.

Furthermore, Table $2 \mathrm{a}$ shows that in the low concentration scenario RCP2.6 the winter temperature increases stronger than summer temperature. This is consistent with most global climate simulations [e.g. Jones and Briffa (1992), Huang et al. (2012), and Cohen et al. (2012)] who found northern hemisphere winter temperatures to increase stronger than summer temperatures during the twentieth century warming trend. However, for the higher emission scenarios RCP4.5 and RCP8.5 Table 2a clearly indicates a reversal of this seasonal asymmetric forcing as temperature either increase equally strong over the seasons (RCP4.5) or even increase more during summer (RCP8.5) at the end of the century.
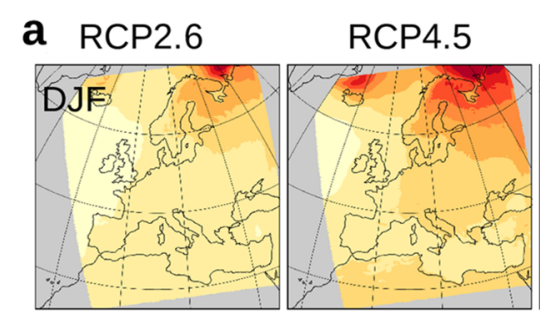

\section{RCP8.5}
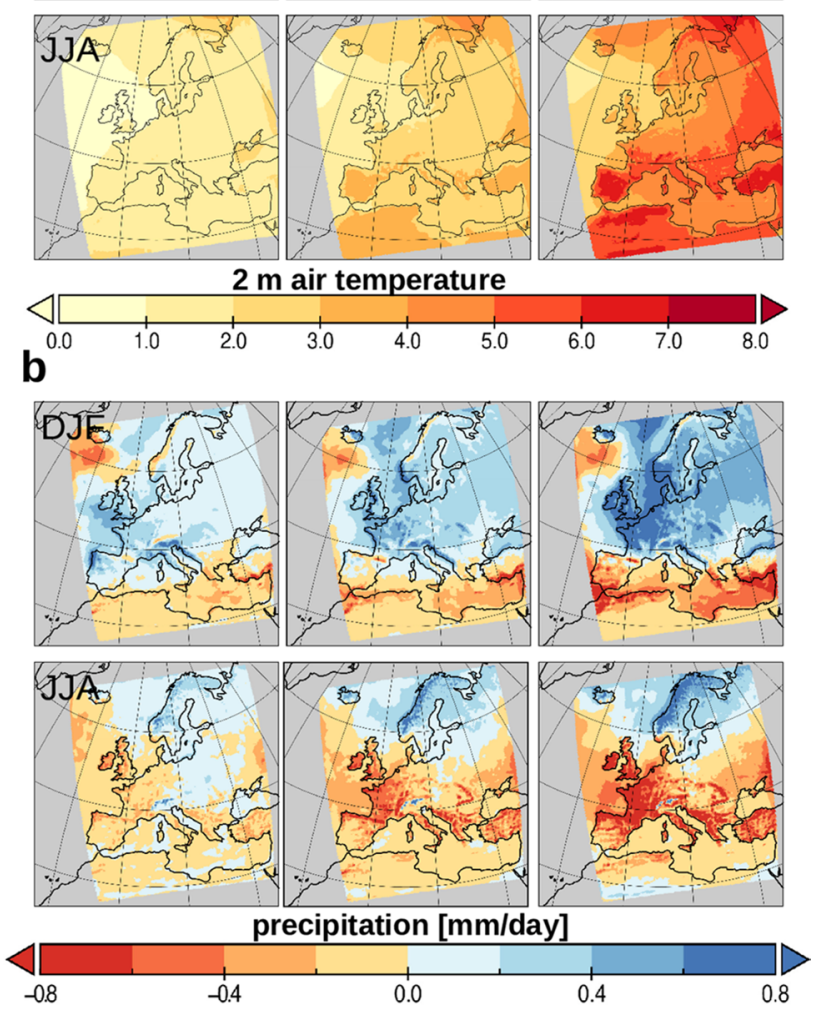

Fig. 8 a Change in T2m between 2070-2099 minus 1970-1999 for winter season (upper panel) and for summer. (lower panel). b Same as (a) but for precipitation. Shown is the respective mean over all nine ensemble members

Figure 8 a demonstrates the asymmetric warming with respect to the cold and warm seasons. During winter strongest warming is seen in the northern high latitudes which results from substantially reduced snow cover over land and reduced sea ice cover in the Arctic leading to overall elevated heat fluxes from the ocean to the atmosphere there. In addition the black body radiation is less efficient at lower temperatures characteristic for high latitudes. During summer, strong warming is seen in a zonal band south of $\sim 45^{\circ} \mathrm{N}$ whereas in the high latitudes the aforementioned albedo feedbacks that operate during winter are strongly reduced. In addition the warming increases towards the eastern continental land mass as well as over the northern African continent overall resulting in a pronounced landsea warming pattern. During summer (Fig. 8a, lower panel) ice-albedo feedbacks are of minor importance leading to reduce warming anomalies in the high latitudes compared 
to winter. Furthermore, the high latitudes undergo more winter precipitation (Fig. 8b) which generates increased latent heat loss that damps the warming compared to the southern part of Europe. Thus, during summer the anomaly pattern is influenced by the large scale thermal response of the North Atlantic as well as reorganization of the water cycle.

Figure $8 \mathrm{~b}$ displays the seasonal changes in precipitation. A pronounced north south pattern with increased precipitation in the north and dryer conditions in the south are seen indicating stronger moisture convergence over northern Europe. This pattern is well known from previous assessments (Christensen et al. 2001, 2007; Collins et al. 2013) and previous results for the Euro-CORDEX region (Jacob et al. 2014; Kjellström et al. 2018). Gröger et al. (2019) linked the north-south pattern to a northward shift of the westerlies during the warm season. Less precipitation is likewise seen during winter south of Iceland. This probably indicates a northward shift of the mean position of the Icelandic Low Pressure System. Such a northward shift in northern hemisphere sub-polar low pressure systems was not only detected in climate scenarios over the North Atlantic (e.g. $\mathrm{Hu}$ and $\mathrm{Wu} 2004$ ) but also reported for the Aleutian Low in the Pacific sector (Gan et al. 2017). The region which is most impacted by the large scale atmospheric moisture transports is centered around France where a tremendous intensification of precipitation is seen during winter while dryer conditions are expected during summer. This is most pronounced in the high concentration scenario RCP8.5 but notable even in RCP2.6.

\subsubsection{Changes in extremes}

Depending on the respective climate scenario we showed profound changes in mean seasonal temperature and precipitation. In this section we will explore the climate change impact on anomalous weather conditions.

\subsubsection{Dry periods}

Figure 9a shows distribution of dry periods during summer within the historical period for each of the ensemble members. Generally, three zonal bands can be distinguished: (1) the southern part around North Africa and the Mediterranean is dominated by long lasting droughts which limit the total number of individual 5-days dry periods, (2) the temperated regions in South Europe containing the maximum number of dry periods, and (3) northern Europe and the North Atlantic with lower occurrences of dry periods. Local maxima can be seen in individual model realizations like high frequencies over the western Mediterranean (Had,IPSL) or in semi-aride regions continental eastern Europe.

The general response to climate change can be assessed by the mean change over the whole ensemble (Fig. 9c). In the more intense greenhouse gas scenarios RCP4.5 and RCP8.5 a robust increase is seen between 45 and $60^{\circ} \mathrm{N}$. This is in accordance with the mean seasonal climate change signal that reveals higher precipitation rates in this region during summer (Fig. 8b, lower panel). In southern Europe and North Africa dry periods decrease, mainly due to a further increase in the duration of droughts (Fig. 9d). This is also true for the southern part of Iberia where likewise less dry periods are seen. Northernmost Europe is more or less unaffected showing changes of only a few percent less dry periods at the end of the century. The strongest impact is seen over the UK, France, western Germany, Austria, and Swiss where a strong decline of seasonal mean precipitation is registered at the same time (Fig. 8b). Over the UK, the Alps region and along the Carpathian orogen the number of dry periods is more than twice as high in RCP8.5 than during the historical period. In the RCP8.5 scenario, the average duration of dry periods increases maximal in those regions which suffer already under present climate from pronounced droughts, i.e. over northeastern Africa, the eastern Mediterranean and the southern Iberian Peninsula. In the latter region the area impacted by severe drought (i.e. dry periods longer than 50 day duration) penetrates further north. Even in the southwestern part of France the average duration of dry periods increase up to 15 days. With regard to the respective climate scenario we can conclude that the pattern of simulated changes is more or less the same in all scenarios when considering the mean over all model realizations (Fig. 9c, d). This indicates a proportional scaling of the climate change pattern to the imposed increase in greenhouse gas concentrations. However, strong deviations from this general pattern can occur on the local scale by individual ensemble members (Fig. 9b). This is most obvious over Scandinavia and the northernmost Atlantic where strong negative anomalies are simulated (e.g. GFDL, NORESM) or no significant changes are registered or even slight increases (CAN, ECE). We further conclude that the climate mitigation scenario RCP2.6 avoids most severe impacts seen in the scenarios without mitigation. Hence in most realizations changes become hardly significant (Fig. 9b) nor show up a robust response over the model ensemble (Fig. 9c, d) indicating that the climate change signal in most regions remains below the models internal stochastic forcing.

\subsubsection{Impact on frequency and duration of hot spells.}

Unlike the climate change impact on dry periods which shows a distinct pattern of zonal bands of increasing and decreasing frequencies (Fig. 9) hot spells increase almost everywhere (Fig. 10c) which is in accordance with the widespread warming of seasonal mean summer climate seen in Fig. 8a. A slight but nevertheless robust decline of hot spells is only seen in the southern Iberian Peninsula and the eastern 


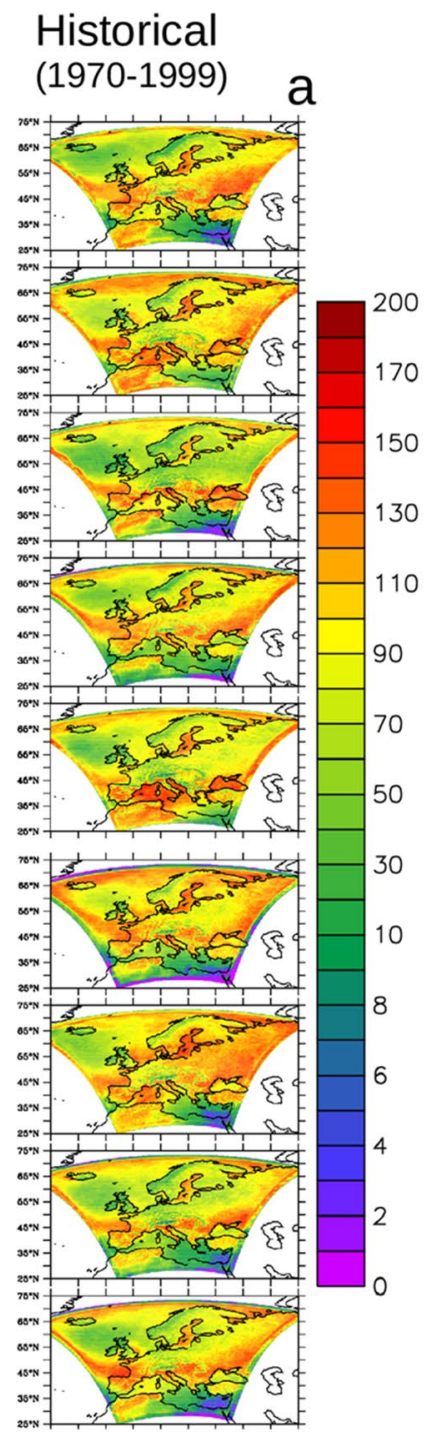

\section{Difference to historical time}

RCP2.6 RCP4.5 RCP8.5

(2070-2099) (2070-2099) (2070-2099)

$b$
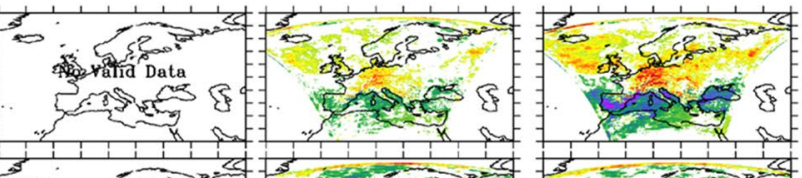

CNRM

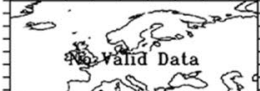

.
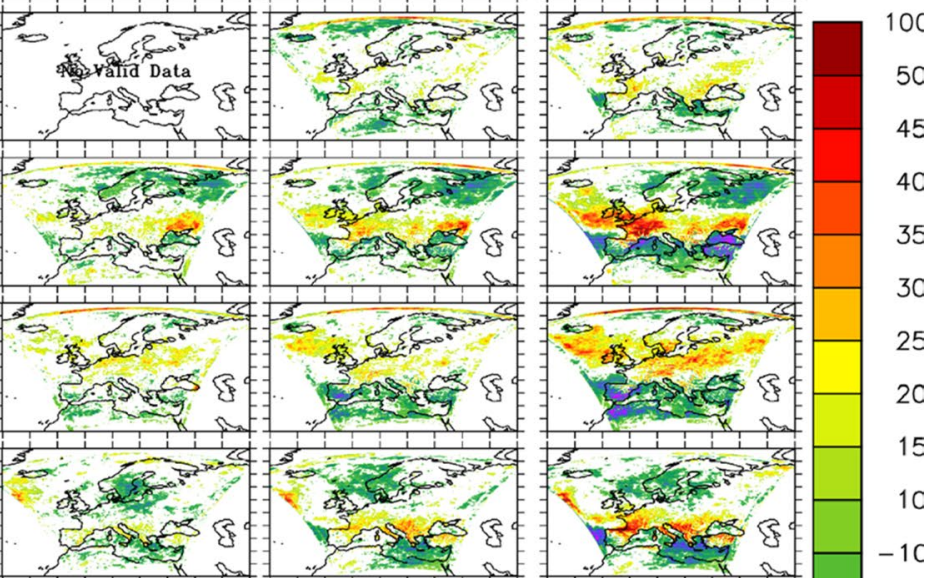

MPI

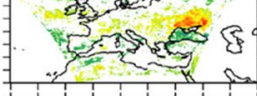

CAN

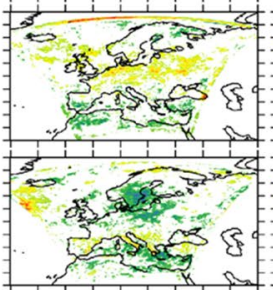

HAD
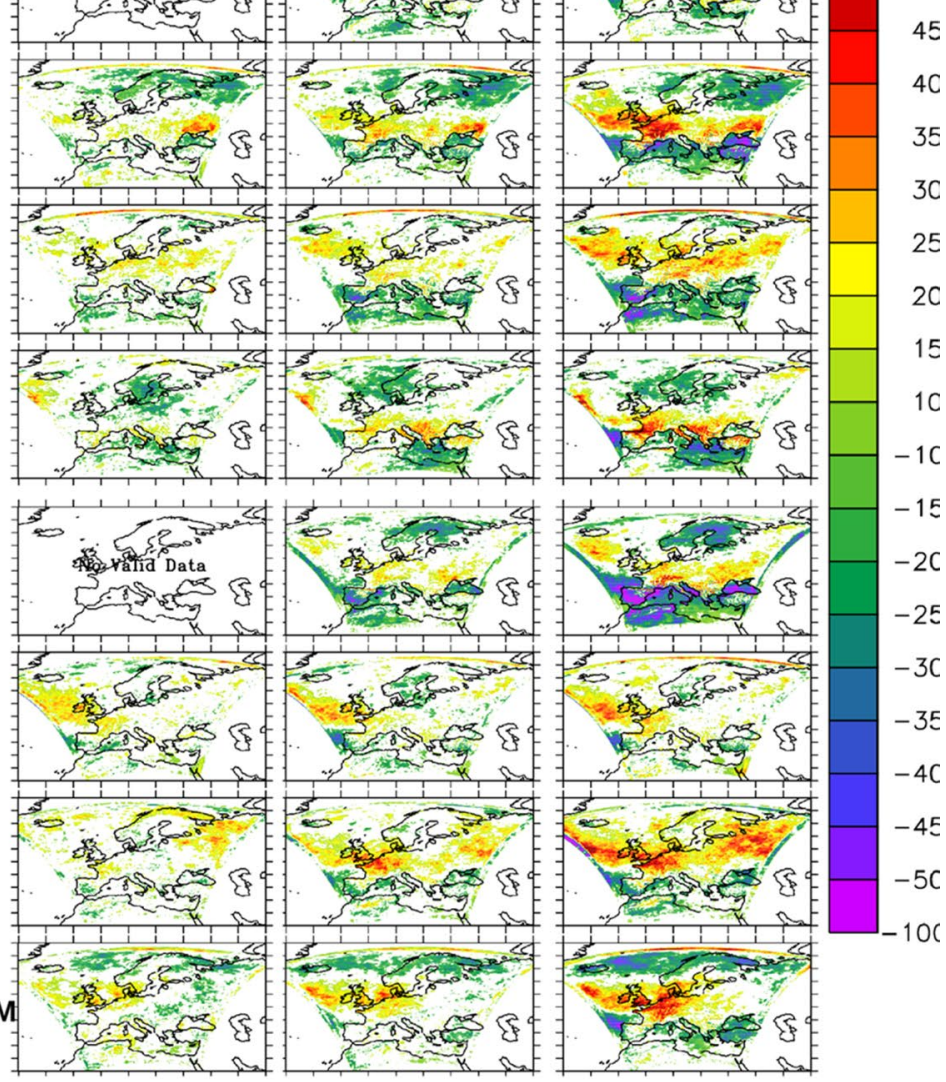

GFDL

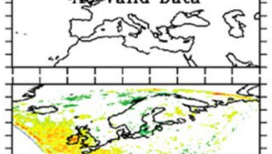

IPSL
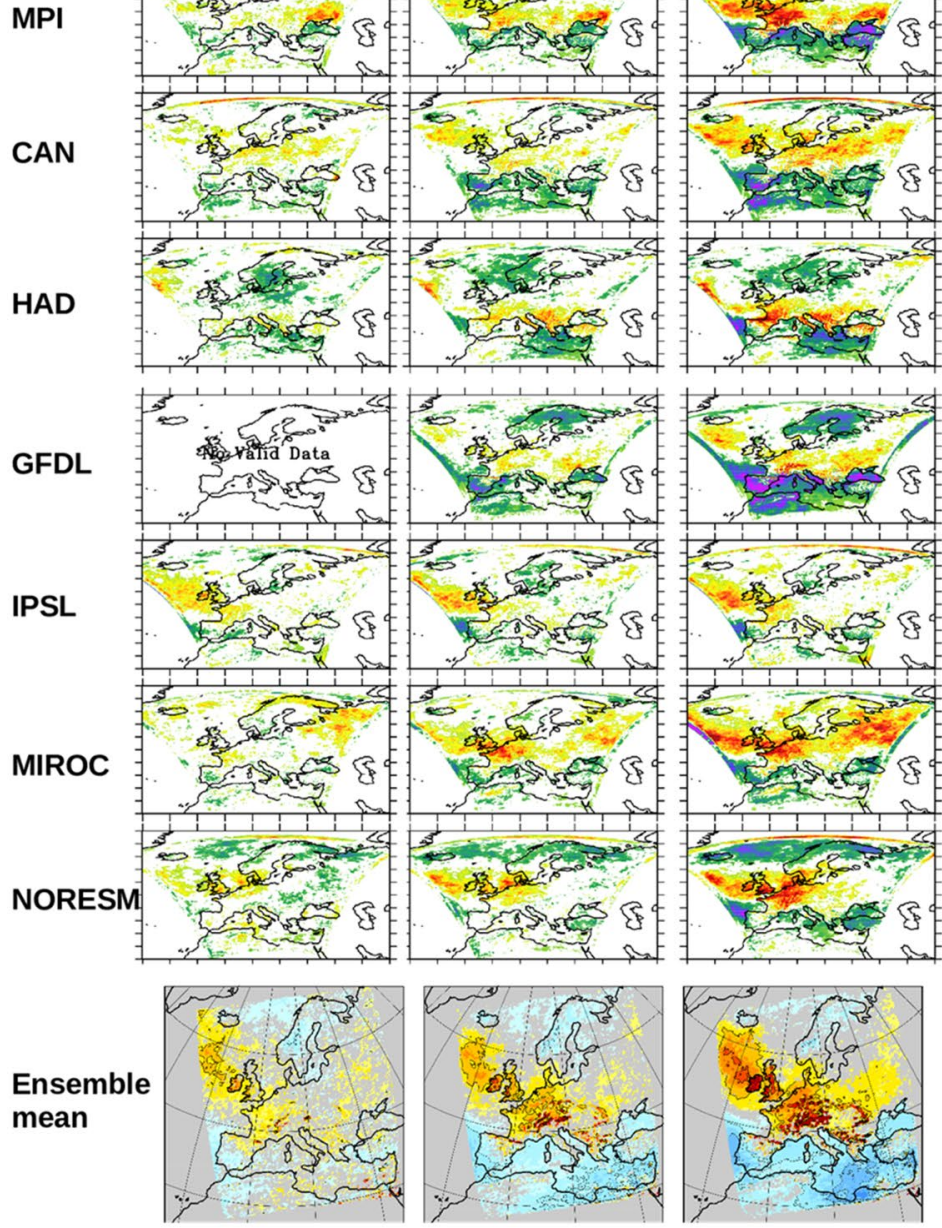

35
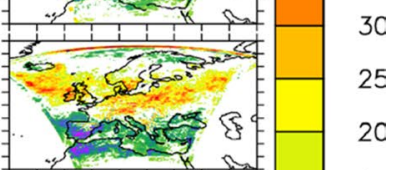

25

$2 \mathrm{C}$

15
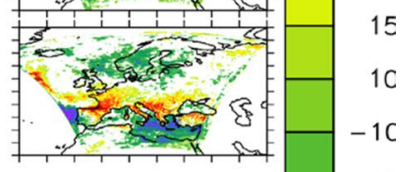

Change in no. of periods

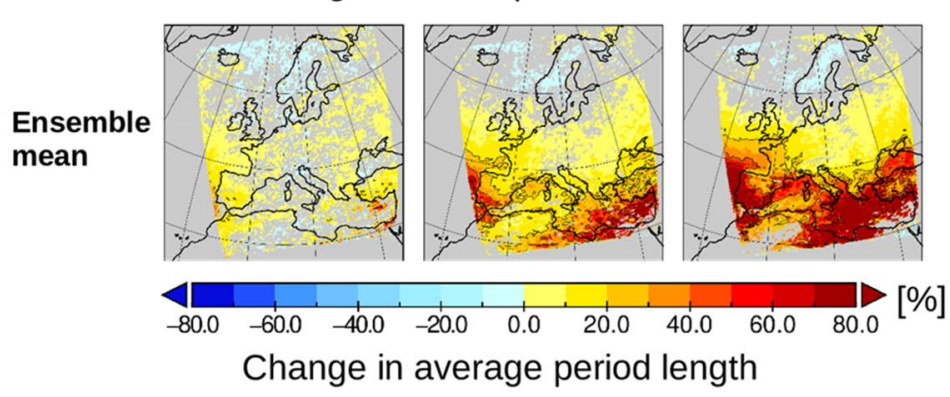

d

C
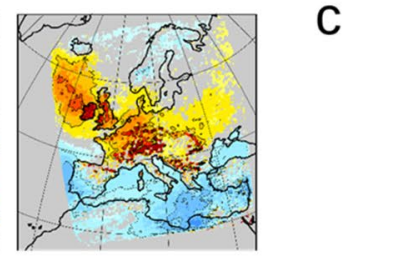

Fig. 9 a Left: Number of periods $>5$ consecutive dry days $(\leq 1 \mathrm{~mm} /$ day) during summer (JJA). b Difference 2070-2099 minus 19701999 in number of dry periods. Only changes significant at the $95 \%$ confidence level are shown. c Ensemble mean change (2070-2099 minus 1970-1999) in no of dry periods. Only robust changes are shown. d Same as (c) but for average period length 

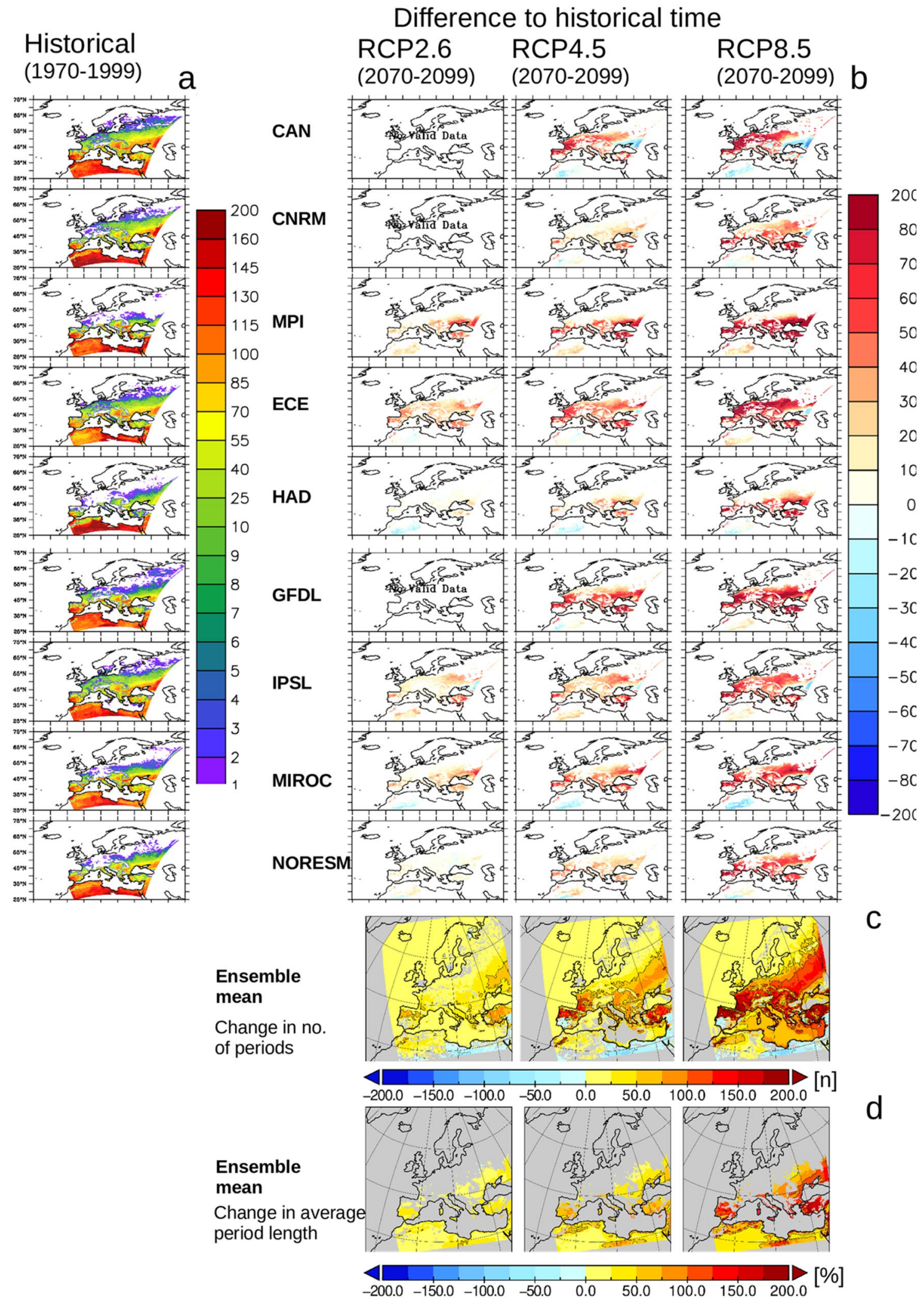

Fig. 10 a Number of periods $>5$ consecutive hot days $\left(>30{ }^{\circ} \mathrm{C}\right)$ during summer (JJA). Note the scale change from 10 to 25 periods in the color scale. b Difference 2070-2099 minus 1970-1999 in number of hot spells. Only changes significant at the 95 th\% confidence level are shown. c Ensemble mean change (2070-2099 minus 1970-1999) in no. of hot spells. Only robust changes are shown. d Same as (c) but for average length of hot spells. Only grid cells are plotted for which all nine ensemble members have in (a) values 
part of northernmost Africa (Fig. 10c). The northern part of Europe, i.e. Scandinavia, and Iceland and northernmost Russia are more or less unaffected by climate change. In the high concentration scenarios RCP4.5 and RCP8.5 the strongest frequency increase is concentrated over the northern Iberian Peninsula, southwestern France, and Turkey. In wide parts over Turkey not only the frequency of hot spells increases tremendously but the duration of hot spells enhances at the same time (Fig. 10d). This is also true for parts of the Balkans and north of the Black Sea. Figure 10b demonstrates that the strongest changes seen in todays temperated regions of Europe are the most significant in a zonal band ranging from about $40-50^{\circ} \mathrm{N}$ and whereas north and south of this band changes do not exceed stochastic forcing. This is even true for the highest concentration scenario.

The stronger thermal response in the mean summer temperature over the Mediterranean compared to the North Atlantic (Fig. 8a) translates likewise into stronger frequency increases. The effect of atmospheric heat loss during the warm season is also seen in the North Sea and Baltic Sea even though the latter shows a relatively strong increase in average summer temperature compared to the North Atlantic and the North Sea. Furthermore, even though some of the model realizations show already a notable significant increase in hot spell frequencies in the RCP2.6 scenario (e.g. ECE, MPI,MIROC) it is obvious that the strongest climate induced impacts seen in RCP4.5 and RCP8.5 can be avoided by mitigation efforts.

\subsubsection{Tropical nights}

The pattern of changed tropical night abundance is shown by the model ensemble mean for the three respective climate scenarios (Fig. 11). As expected, tropical nights are more frequent in the high concentration scenarios and south of $45^{\circ} \mathrm{N}$. Overall, the strongest increases of tropical nights occur over open sea areas around southern Europe. Changes over land areas are less intense with the exception of North Africa. In continental Europe changes are moderate and tropical nights remain a rare phenomenon at least in RCP2.6, and RCP4.5 where such events occur only a couple of days per year. Only in the Panonian basin southwest of the Carpathian orogen increase by up to 300 nights per 30 year (RCP2.6) and 600 nights per 30 year (RCP4.5). Changes of similar magnitude are seen north of the Black Sea. In RCP8.5 however, tropical nights become more frequent also in most other regions of continental Europe. Over land the response does not only depend on the scenario but also from local topography. The strongest impact is seen in southern Europe in areas with moderate elevation, e.g. the southern Iberian Peninsula, Italy, and western Turkey while pronounced orogenic regions like the Carpathians, the Pyrenees, and elevated areas of eastern Turkey are only weakly

\section{RCP2.6 RCP4.5 RCP8.5}

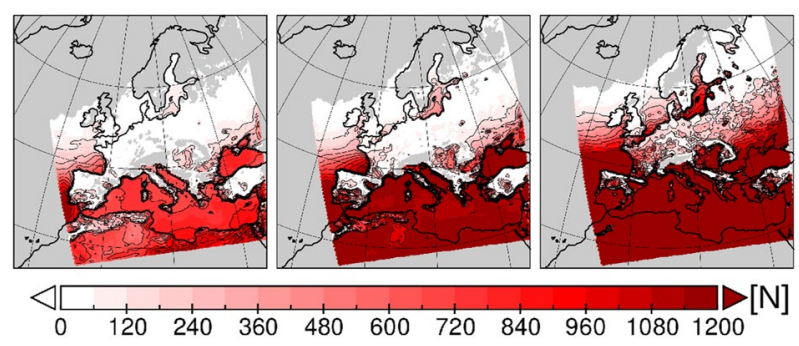

Fig. 11 Number of tropical nights within 2070-2099 in the 3 concentration scenarios RCP2.6, RCP4.5, and RCP8.5. Tropical nights are defind as days where the minimum temperature does not fall below $20{ }^{\circ} \mathrm{C}$. Shown is the difference to the historical period (2070-2099 minus 1970-1999). A bias adjusted figure is available from the Suppl. Mat. S3)

affected. Only in Scandinavia and northernmost part of Russia tropical nights remain rare or are completely absent.

Open sea regions characterized by moderate water temperature under present day climate can be considered as hot spots for the impact of the climate change scenario in this regard. Example are the Bay of Biscaya, the North Sea as well as the Baltic Sea. While moderately increasing water temperatures under RCP2.6 have already strong impact on tropical nights in the Bay of Biscaya the latter two marginal seas show strongest responses under the RCP4.5 and RCP8.5 scenarios. In particular the Baltic Sea shows a very strong response in RCP8.5 that strikes out in the zonal band between 50 and $70^{\circ} \mathrm{N}$ (Fig. 11).

\subsubsection{Frost days}

Figure 12a compares the number of frost days between the historical period and the climate scenarios. Those days are completely absent over the southern North Atlantic which demonstrates the effect of the large oceanic heat capacity in this region. This situation is nearly more or less robust across the considered ensemble members and against the different climate scenarios. With stronger the greenhouse gas scenario the areas of frost free days expands a bit further towards the northeast.

A clear atmosphere-ocean feedback is introduced from the interactively coupled North Sea and Baltic Sea high resolution ocean model. Although warming over the Baltic Sea is much stronger than over the North Sea in all the scenarios (Fig. 8a) frost days are still present over the whole Baltic in all models even in the high concentration scenarios RCP8.5 (Fig. 12a). By contrast, the weaker warming over the North Sea already eliminates frost days in RCP4.5 and RCP8.5 at least in its western part. This is related mainly to two processes: (1) During winter the North Sea receives warmer waters from the North Atlantic that enter east of 


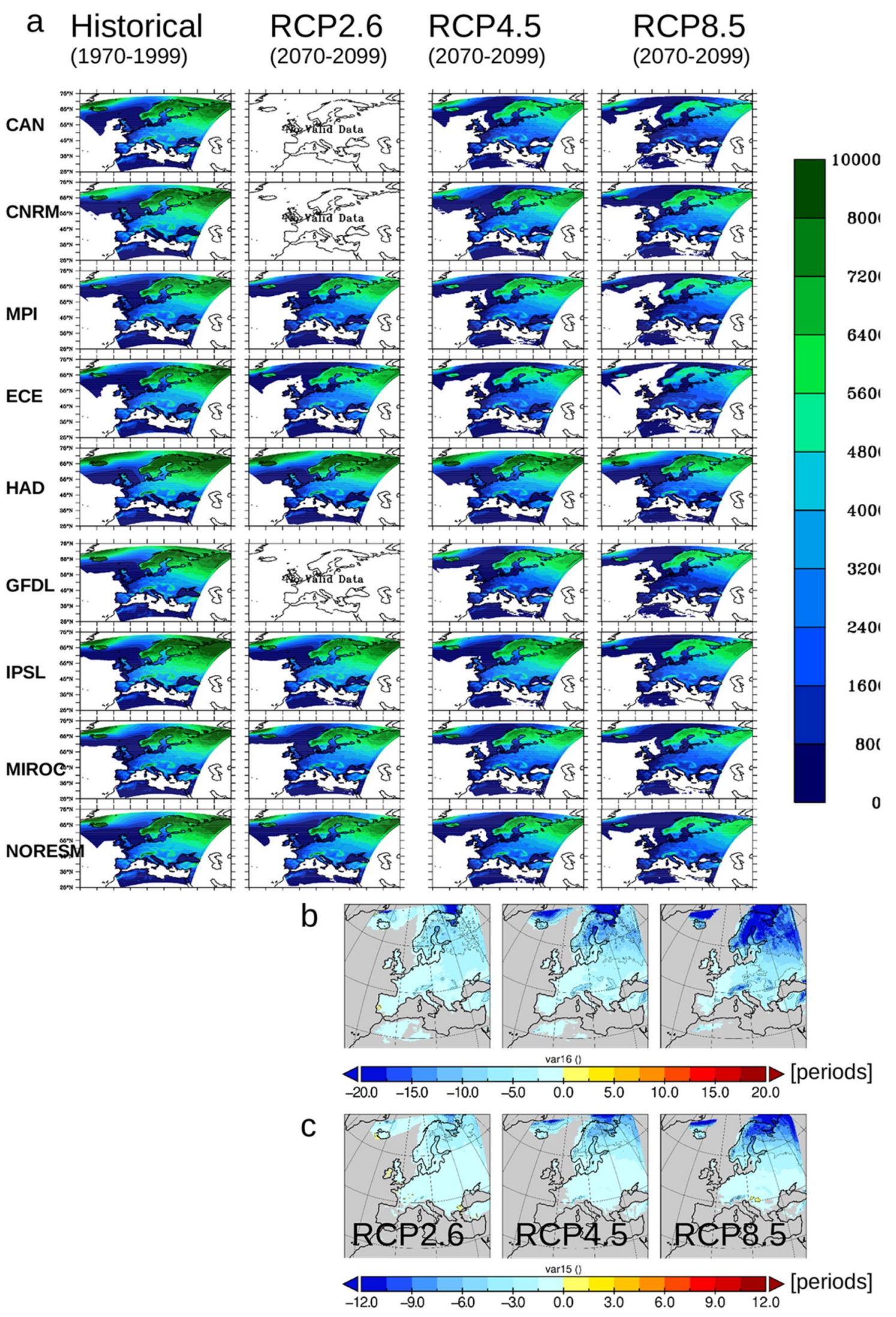


4Fig. 12 a Number of frost days in the historical period (1970-1999) and the three climate scenarios. b Average period duration [days] of periods of at least 5 consecutive frost days. Shown is the mean over the model ensemble. Shown are only robust changes over the ensemble. c Same as (b) but for periods of at least 3 consecutive ice days. A bias adjusted figure is available from the Suppl.Mat. S4

Scotland and spread southward along the eastern coast of the UK. In addition, the North Sea is well mixed during the winter season which increases the effective heat capacity. It therefore responds much slower to the winter cooling (Gröger et al. 2015). By contrast the eastern North Sea is marked by inflow of low salinity water from the Baltic Sea. These waters spread northwards along Norwegian channel and impose a strong haline stratification thereby lowering the effective heat capacity and promoting rapid winter cooling there. As a result of these small scale ocean processes that are explicitly resolved in the online coupled high resolution ocean model, the North Sea shows a clear east-west pattern where frost days are absent in the western part and still present in the eastern part even in the strongest warming scenario RCP8.5. This is the case in not less than 7 out of nine model realizations shown in Fig. 12a.

Over land an overall strong decline of frost days is seen which is most pronounced over northern Scandinavia and adjacent northern Russia. However, most affected is western Europe where the relative changes vary between 50 and $80 \%$ in the multi model average in RCP8.5 whereas in the mitigation scenario RCP2.6 the corresponding change reduces to $10-30 \%$. It is noteworthy that even in the highest concentration scenario frost day exist over North Africa. This is probably linked to the poor vegetation cover in the region which supports a rapid cooling over night even in the high concentration scenario RCP8.5.

Figure $12 \mathrm{~b}$ displays changes in the duration of periods of at least 5 consecutive days. The strongest response is seen in the northernmost land areas where the period length declines by up to more than 20 days indicating a more frequent interruption of frost periods in these regions. Further south with the exception of elevated regions like the Alps frost periods change only slightly. Thus, at first order the overall pattern follows the distribution frost periods abundance in the control period. All this applies also to periods of at least 3 consecutive ice days displayed in Fig. 12c.

\section{Discussion}

\subsection{Interactive air-sea coupling over land}

Next the question is addressed if interactive air-sea coupling can have a pronounced effect on climate change at the end of the century in scenarios RCP4.5 and RCP8.5. For this, we will elaborate on how the coupled ensemble differs from the high resolution Euro-CORDEX ensemble provided by Jacob et al. (2014). With respect to the found changes in heat waves and dry spells, the coupled ensemble is in line with EuroCORDEX ensemble (e.g. Jacob et al. 2014). This is likewise true for the changes in mean seasonal climate change (Jacob et al. 2014; Kjellström et al. 2018; Rajczak and Schär, 2017). To further demonstrate this we now provide a more quantitative measure for the consistency with available results from previous studies. We follow Jacob et al. (2014) who calculated a number of climate indices for European subregions and their change at the end of the twenty-first century according the RCP4.5 and RCP8.5 scenarios. Following Metzger et al. (2005) 17 subregions can be distinguished based on variation in climate and ecosystems in Europe. For analysis, the subregions were further summarized to reduce complexity yielding a total of five main regions that were used in the analysis of European climate change in the IPCC AR5 report. These indices are then compared to those from the most recent Euro-CORDEX ensemble calculated in the same way by Jacob et al. (2014, Table 3). We note that the climate indices were determined only over land grid cells to ensure consistency with Jacob et al. (2014).

The majority of analyzed indices $(\sim 83 \%$ or 50 out of 60 ) fall well into the likely range and $\sim 93 \%$ are within the minimum and maximum ranges given in Jacob et al. (2014). The calculated indices for mean $\mathrm{T} 2 \mathrm{~m}$ air temperature, frost days, and the two precipitation indices are almost completely within the likely range. Notable deviations are seen in the number of summer days which are however still within the min and max range of the Euro-CORDEX ensemble. All deviations are positive indicating that the coupled ensemble is in the upper range of the Euro-CORDEX ensemble. This may reflect that the coupled ensemble is a too cold during the historical period (Fig. 8a, Suppl. Mat. S1) which makes the model more sensitive to warming as less effective longwave back-radiation at low temperatures together with positive (snow-albedo) feedbacks tend to enhance warming. The most pronounced difference is clearly seen in the increase of tropical nights which is some orders of magnitude higher compared to the Euro-CORDEX ensemble (Table 3). The strongest response is seen in the Alpine sub-region both for RCP4.5 and RCP8.5 and for the Northern sub-domain for RCP8.5. However, this is most likely not an effect of interactive coupling but rather results from the coarser horizontal resolution of the coupled ensemble $\left(0.22^{\circ}\right)$ compared to Euro-CORDEX ensemble $\left(0.11^{\circ}\right)$. Since the representation of mountainous areas is strongly depended on resolution it is likely that with coarser resolution, adjacent areas of lower elevation contribute to the Alpine area defined by Metzger et al. (2005). Consequently, the Alpine area is more sensitive with respect to threshold based indices like tropical nights. Thus, from the quantitative comparison for European 


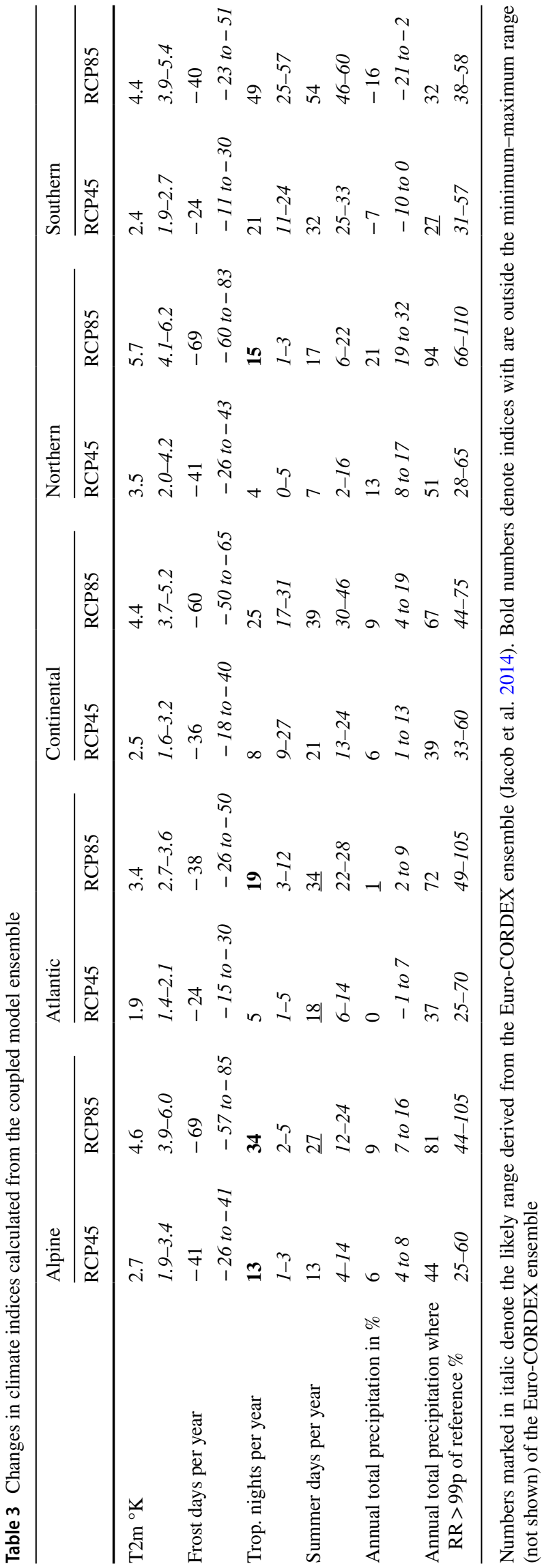

sub-regions and neglecting open ocean areas we can conclude interactive coupling has no notable effect on indices over land that are averaged over large spatial and temporal scales.

Confirming most global climate simulations, this study finds a stronger warming of land areas compared to open ocean areas for the European sector. In the ensemble averages land areas warm up by about 1.5 times faster than the ocean areas in all the considered scenarios (Table 2). Thus thermal land-sea contrasts may be less pronounced during winter and more pronounced during summer in the future climate. This may affect the intensity and pathway of cyclones that enter Europe from the Atlantic. Such effects have been detected in global climate simulations for the Arctic where storminess intensified during the summer season when land-sea contrast were intensified compared to the present climate (Day and Hodges 2018).

\subsection{Interactive coupling over sea}

We now aim to explore the differences between the coupled and the uncoupled model directly over the open sea areas of the coupled domain, i.e. the North Sea and Baltic Sea. For this we compare two runs for the present day climate forced by ERA40 reanalysis data. One run is fully coupled while the other uses ERA40 SST as atmospheric boundary condition over open water.

Figure s13a shows the difference in simulated seasonal $\mathrm{T} 2 \mathrm{~m}$ for the hindcast period 1970-1999. It is clearly seen that the coupled model shows almost everywhere warmer $\mathrm{T} 2 \mathrm{~m}$ over the coupled region compared to the uncoupled model (Fig. 13a). The lower T2m in the uncoupled run can be related to a substantial cold bias of the ERA40 SSTs (compared to observational data of Federal Maritime and Hydrographic Agency, Hamburg, Germany) prescribed at the models lower boundary (Gröger et al. 2015). It was also found that the coupled model does considerably reduce this bias at the sea surface. Figure 13a further demonstrates that the differences are mostly restricted to the coupled region. The most likely reason for this is the intense dispersive energy transport of the atmosphere compared to the ocean. In addition, the Baltic Sea and North Sea area must be considered small compared to the whole model domain. As a result, temperature anomalies generated in the coupled ocean are prevented from extending too far inside land areas. Consequently, the air-sea coupling effect on land is restricted to the coastal regions (Fig. 13a). However, notable effects on land coastal areas are seen especially during warm seasons (summer and autumn) when the anomalies over the Baltic Sea are highest. At this time $\mathrm{T} 2 \mathrm{~m}$ anomalies over land can exceed $0.3 \mathrm{~K}$ along the coasts.

Summer and autumn are also the seasons where the ocean-atmosphere heat exchange differs most between 
Fig. 13 a Difference of T2m between coupled minus uncoupled ERA40 hindcast simulation for the period 1970-1999. b Sea to air heat flux average over the area of the Baltic Sea
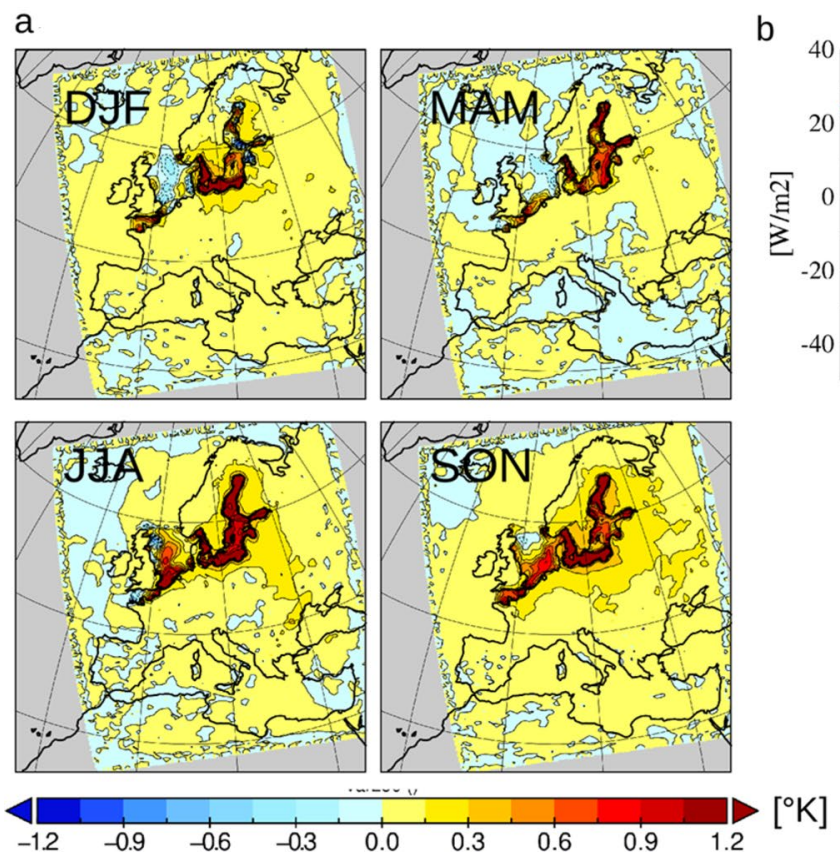

b

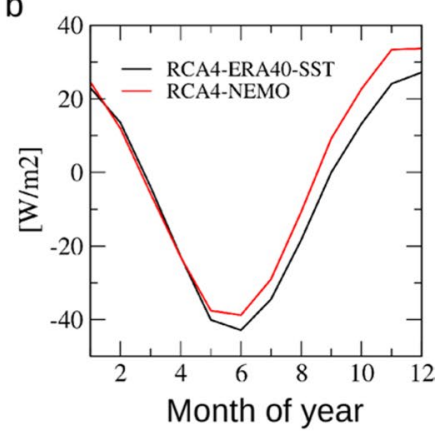

coupled and uncoupled simulations (Fig. 13b). During summer when the atmosphere is warmer than the ocean sea to air fluxes are negative. This heat transfer to the ocean is less strong in the coupled model where the ocean is allowed to warm thereby reducing the atmosphere-ocean temperature gradient. With the beginning of autumn the atmosphere cools faster than the sea and the sea to air heat flux becomes positive. Here the resulting ocean to atmosphere heat flux is bigger in the coupled model (Fig. 13b).This is somewhat surprising as one would expect the ocean will cool in the coupled model and reduce air sea temperature contrasts thereby lowering heat fluxes. However, this is not the case as previously shown by Gröger et al. (2015) due to a feedback simulated only by the coupled ocean model. Accordingly, widespread strong sea to air heat fluxes destabilize the atmospheric boundary layer resulting in stronger winds further translating into a deeper ocean mixed layer. This prevents the ocean surface from too strong cooling as warmer water from deeper water layers reaches the surface (Gröger et al. 2015). As a result, the coupled - uncoupled T2m difference is highest during summer and autumn (Fig. 13b).

The strong thermal response to interactive air-sea coupling will likely also influence most temperature related climate indices. An example is the response of tropical nights in the future climate. Teichmann et al. (2018) calculated tropical nights for global warming levels of $+1.5 \mathrm{~K},+2 \mathrm{~K}$, and $+3 \mathrm{~K}$. For this the authors used uncoupled Euro-CORDEX atmosphere scenarios using SSTs from global models at the lower boundary. However, no substantial increases of tropical nights over the Baltic Sea are reported and north of $55^{\circ} \mathrm{N}$ tropical nights are mostly absent even at the strongest warming level of $3 \mathrm{~K}$ (see Fig. 2 in Teichmann et al. 2018). By contrast, the usage of an interactively coupled ocean model identifies the Baltic Sea as a hot spot of tropical nights in future climate.

These findings will have consequence for marine and coastal climate change impact studies. Data from uncoupled climate projections were used in several studies to drive regional ocean models for specific marine applications (e.g. Friocourt et al. 2012; Kjellström and Ruosteenoja 2007; Omstedt et al. 2012; Tinker et al. 2015, 2016; Tian et al. 2016; Pätsch et al. 2017; Höglund et al. 2017).

\subsection{Limitations}

In our ensemble interactive air sea coupling impacts mainly directly over the coupled region and along the coasts. Over wider land areas calculated climate indices are statistically indistinguishable from published uncoupled ensembles (Jacob et al. 2014). However, the weak air sea coupling effect over land areas should not be generalized as some uncertainties are associated with our model configuration. First, the coupled area, i.e. the North Sea and Baltic Sea cover only $800,820 \mathrm{~km}^{2}$ which constitutes only a small part of the entire open ocean area within the Euro-CORDEX domain. In addition, the coupled North and Baltic Seas are shallow marginal shelf seas with only a small water volume which limits their effective heat inventory and thus, the ability to influence the thermal dynamics of the atmosphere on a large scale beyond the coupled domain.

The key parameter for the found differences is the representation of SSTs and sea ice in the atmospheric boundary 
layer. In uncoupled simulation these fields have to be derived from global ocean models which do not resolve oceanic key processes, such as the oceans thermocline dynamics, vertical mixing and heat transport in the North Sea and Baltic Sea, and which are sensitive to air-sea coupling.

The future trend of regional climate modelling will demand for higher horizontal resolution up to convection permitting scales of only a few kilometers (Giorgi 2019; Jacob et al. 2020). At these resolution interactive air sea coupling can be expected to be more beneficial. With the resolution used in our study, SST fields are simulated with a resolution of two nautical miles $(\sim 3.7 \mathrm{~km})$. But, these fields have to be interpolated on the atmospheric grid at $\sim 22 \mathrm{~km}$ resolution. Accordingly, small scale SST patterns like strong gradients along the transition from the coasts to the open sea are strongly smoothed which hampers the representation of realistic land-sea dynamics. However, with increasing resolution of the atmosphere model, the additional relative consumption of CPU resources by the ocean model decreases and makes coupled ocean atmosphere models economically less demanding.

Finally, this study does not take into account corresponding biophysical feedbacks from interactive atmophere-land coupling simulated by interactive dynamical vegetation models. Today, such biophysical effects are mostly passively taken into account through scenarios for future land use (e.g. Jacob et al. 2020) assuming that the land surface is mainly managed rather than subject to climate change. However, climate-vegetation interactions have been shown to be important in less dense populated areas (e.g. Wu et al. 2016) but may be also important in the context of protected land areas and for natural landscape restoration actions.

\section{Conclusions}

For the first time, we present scenario simulations for Europe with a regional high-resolution atmosphere-ocean model including the interactively coupled Baltic Sea and North Sea based upon an ensemble of nine global climate models and three greenhouse gas concentration scenarios (RCP2.6, RCP4.5 and RCP8.5). The large ensemble allows to estimate uncertainties of projections whereas previous studies with coupled models focused on mini-ensembles only. In addition to ensemble mean changes, we analyzed the changes of selected extremes. Over land, we found similar changes in our scenario simulations compared to the results of previous studies of the Euro-CORDEX project. However, we found different results over the Baltic Sea and North Sea. In particular, our projections suggest that tropical nights increase significantly over the Baltic Sea and adjacent coastal regions in future climate whereas uncoupled projections showed almost no change. We found that the results are explained by feedback mechanisms of the coupled model that are missing in uncoupled projections. We conclude that the usage of climate change data from uncoupled model ensembles such as the Euro-CORDEX data should be treated with caution over open sea areas and the adjacent coastal zones.

Acknowledgements Funding was obtained from the MERCATOR CMEMS Service Evolution 66-SE-CALL2 "Regionally downscaled climate projections for the Baltic and North Seas (CLIMSEA)". Further funding was obtained from the project CoClime. Project CoCliME is part of ERA4CS, an ERANET initiated by JPI Climate, and funded by EPA (IE), ANR (FR), BMBF (DE), UEFISCDI (RO), RCN (NO) and FORMAS (SE), with co-funding by the European Union (Grant 690462). Further funding was obtained from the project ClimeMarine funded by the Swedish Research Council Formas within the framework of the National Research Program for Climate (Grant no. 2017-01949).

Regional climate scenario simulations have been conducted on the Linux clusters Krypton, Bi, Triolith and Tetralith, all operated by the National Supercomputer Centre in Sweden (NSC, https://www.nsc.liu. se/). Resources on Triolith and Tetralith were funded by the Swedish National Infrastructure for Computing (SNIC) (Grants SNIC 002/1225, SNIC 2018/3-280 and SNIC 2019/3-356).The research presented in this study is part of the Baltic Earth program (Earth System Science for the Baltic Sea region, see https://www.baltic.earth).

Open Access This article is licensed under a Creative Commons Attribution 4.0 International License, which permits use, sharing, adaptation, distribution and reproduction in any medium or format, as long as you give appropriate credit to the original author(s) and the source, provide a link to the Creative Commons licence, and indicate if changes were made. The images or other third party material in this article are included in the article's Creative Commons licence, unless indicated otherwise in a credit line to the material. If material is not included in the article's Creative Commons licence and your intended use is not permitted by statutory regulation or exceeds the permitted use, you will need to obtain permission directly from the copyright holder. To view a copy of this licence, visit http://creativecommons.org/licenses/by/4.0/.

\section{References}

Adloff F, Jordà G, Somot S, Sevault F, Meyssignac B, Arsouze T, Li L, Planton S (2017) Improving sea level simulation in Mediterranean regional climate models. Clim Dyn, Med-CORDEX special issue $1-12$

Akhtar N, Brauch J, Ahrens B (2017) Climate modeling over the Mediterranean Sea: impact of resolution and ocean coupling. Clim Dyn, Med-CORDEX special issue 1-16

Bartók B, Wild M, Folini D, Lüthi D, Kotlarski S, Schär C, Vautard R, Jerez S, Imecs Z (2017) Projected changes in surface solar radiation in CMIP5 global climate models and in EUROCORDEX regional climate models for Europe. Clim Dyn 49(7-8):2665-2683

Bersch M, Gouretski V, Sadikni R, Hinrichs I (2013) KLIWAS North Sea climatology of hydrographic data (version 1.0). World Data Center Clim (WDCC). https://doi.org/10.1594/WDCC/ KNSC_hyd_v1.0

Boé J, Somot S, Corre L, Nabat P (2020) Large differences in Summer climate change over Europe as projected by global and regional climate models: causes and consequences. Clim Dyn. https://doi. org/10.1007/s00382-020-05153-1 
Cabos W, de la Vara A, Álvarez-García FJ et al (2020) Impact of oceanatmosphere coupling on regional climate: the Iberian Peninsula case. Clim Dyn 54:4441-4467. https://doi.org/10.1007/s0038 2-020-05238-x

Cardoso RM, Soares PMM, Lima DCA et al (2019) Mean and extreme temperatures in a warming climate: EURO CORDEX and WRF regional climate high-resolution projections for Portugal. Clim Dyn 52:129-157. https://doi.org/10.1007/s00382-018-4124-4

Casanueva A, Kotlarski S, Fischer AM et al (2020) Escalating environmental summer heat exposure-a future threat for the European workforce. Reg Environ Change 20:40. https://doi.org/10.1007/ s10113-020-01625-6

Choudhary A, Dimri AP (2017) Assessment of CORDEX-South Asia experiments for monsoonal precipitation over Himalayan region for future climate. Clim Dyn. https://doi.org/10.1007/ s00382-017-3789-4

Christensen J, Hulme M, Von Storch H, Whetton P, Jones R, Mearns $\mathrm{L}, \mathrm{Fu} \mathrm{C}$ et al (2001) Regional climate information evaluation and projections contents. In: Houghton JT, Ding Y, Griggs DJ, Noguer M, van der Linden PJ, Dai X, Maskell K, Johnson CA (eds) Climate change 2001: the scientific basis. Contribution of Working Group I to the third assessment report of the intergovernmental panel on climate change. Cambridge University Press, Cambridge, p 881

Christensen JH, Hewitson B, Busuioc A, Chen A, Gao X, Held I, Jones R, Kolli RK, Kwon W-T, Laprise R, Magaña Rueda V, Mearns L, Menéndez CG, Räisänen J, Rinke A, Sarr A, Whetton P (2007) Regional climate projections. In: Solomon S, Qin D, Manning M, Chen Z, Marquis M, Averyt KB, Tignor M, Miller HL (eds) Climate change 2007: the physical science basis contribution of Working Group I to the fourth assessment report of the intergovernmental panel on climate change. Cambridge University Press, Cambridge

Christensen JH, Larsen MAD, Christensen OB et al (2019) Robustness of European climate projections from dynamical downscaling. Clim Dyn 53:4857-4869. https://doi.org/10.1007/s0038 2-019-04831-z

Clarke L, Edmonds J, Jacoby H, Pitcher H, Reilly J, Richels R (2007) Scenarios of greenhouse gas emissions and atmospheric concentrations. Sub-report 2.1A of Synthesis and Assessment Product 2.1 by the U.S. Climate Change Science Program and the Subcommittee on Global Change Research. Department of Energy, Office of Biological \& Environmental Research, Washington, 7 DC., USA, pp 154

Cohen JL, Furtado JC, Barlow M, Alexeev VA, Cherry JE (2012) Asymmetric seasonal temperature trends. Geophys Res Lett. https://doi.org/10.1029/2011gl050582

Collins M, Knutti R, Arblaster J, Dufresne J-L, Fichefet T, Friedlingstein P, Gao X, Gutowski WJ, Johns T, Krinner G, Shongwe M, Tebaldi C, Weaver AJ, Wehner M (2013) Long-term climate change: projections, commitments and irreversibility. In: Stocker TF, Qin D, Plattner G-K, Tignor M, Allen SK, Boschung J, Nauels A, Xia Y, Bex V, Midgley PM (eds) Climate Change 2013: the physical science basis. Contribution of Working Group I to the fifth assessment report of the intergovernmental panel on climate change. Cambridge University Press, Cambridge

Colmet-Daage A, Sanchez-Gomez E, Ricci S, Llovel C, Borrell Estupina V, Quintana-Seguí P, Llasat MC, Servat E (2018) Evaluation of uncertainties in mean and extreme precipitation under climate change for northwestern Mediterranean watersheds from highresolution Med and Euro-CORDEX ensembles. Hydrol. Earth Syst. Sci. 22:673-687. https://doi.org/10.5194/hess-22-673-2018

Cornes R, van der Schrier G, van den Besselaar EJM, Jones PD (2018) An ensemble version of the E-OBS temperature and precipitation datasets. J Geophys Res Atmos. https://doi.org/10.1029/2017J D028200

Davin EL, Rechid D, Breil M, Cardoso RM, Coppola E, Hoffmann P, Jach LL, Katragkou E, de Noblet-Ducoudré N, Radtke K, Raffa M, Soares PMM, Sofiadis G, Strada S, Strandberg G, Tölle MH, Warrach-Sagi K, Wulfmeyer V (2020) Biogeophysical impacts of forestation in Europe: first results from the LUCAS Regional Climate Model intercomparison. Earth Syst Dyn 11:183-200. https://doi.org/10.5194/esd-11-183-2020

Day JJ, Hodges KI (2018) Growing land-sea temperature contrast and the intensification of Arctic cyclones. Geophys Res Lett 45:3673-3681. https://doi.org/10.1029/2018GL077587

Dieterich C, Wang S, Schimanke S, Gröger M, Klein B, Hordoir R, Samuelsson P, Liu Y, Axell L, Höglund A, Meier HEM (2019) Surface heat budget over the North Sea in climate change simulations. Atmosphere 10(5):272. https://doi.org/10.3390/atmos 10050272

Dieterich C, Gröger M, Arneborg L, Andersson HC (2019) Extreme sea levels in the Baltic Sea under climate change scenariosPart 1: model validation and sensitivity. Ocean Sci 15:13991418. https://doi.org/10.5194/os-15-1399-2019

Dirmeyer PA, Wang Z, Mbuh MJ, Norton HE (2014) Intensified land surface control on boundary layer growth in a changing climate. Geophys Res Lett 41:1290-1294. https://doi. org/10.1002/2013GL058826

Döscher R, Meier HEM (2004) Simulated sea surface temperature and heat fluxes in different climates of the Baltic Sea. Ambio 33(4):242-248

Döscher R, Willen U, Jones C, Rutgersson A, Meier H, co-authors (2002) The development of the regional coupled ocean-atmosphere model RCAO. Boreal Environ Res 7(3):183-192

Dosio A, Jones RG, Jack C, Lennard C, Nikulin G, Hewitson B (2019) What can we know about future precipitation in Africa? Robustness, significance and added value of projections from a large ensemble of regional climate models. Clim Dyn 53(910):5833-5858. https://doi.org/10.1007/s00382-019-04900-3

Fischer E, Knutti R (2015) Anthropogenic contribution to global occurrence of heavy-precipitation and high-temperature extremes. Nat Clim Change 5:560-564. https://doi. org/10.1038/nclimate2617

Fischer E, Schär C (2010) Consistent geographical patterns of changes in high-impact European heatwaves. Nat Geosci 3:398-403. https://doi.org/10.1038/ngeo866

Frei P, Kotlarski S, Liniger MA, Schär C (2018) Future snowfall in the Alps: projections based on the EURO-CORDEX regional climate models. Cryosphere 12(1):1-24

Frich P, Alexander LV, Della-Marta P, Gleason B, Haylock M, Klein Tank AMG, Peterson T (2002) Observed coherent changes in climatic extremes during the second half of the twentieth century. Clim Res 19:193-212. https://doi.org/10.3354/cr019193

Friocourt YF, Skogen M, Stolte W, Albretsen J (2012) Marine downscaling of a future climate scenario in the North Sea and possible effects on dinoflagellate harmful algal blooms. Food Addit Contam 29(10):1630-1646. https://doi.org/10.1080/19440 049.2012 .714079

Gaertner MÁ, González-Alemán JJ, Romera R et al (2018) Simulation of medicanes over the Mediterranean Sea in a regional climate model ensemble: impact of ocean-atmosphere coupling and increased resolution. Clim Dyn 51:1041-1057. https://doi. org/10.1007/s00382-016-3456-1

Gan B, Wu L, Jia F, Li S, Cai W, Nakamura H, Alexander MA, Miller AJ (2017) On the response of the Aleutian low to greenhouse warming. J Clim 30:3907-3925. https://doi.org/10.1175/ JCLI-D-15-0789.1 
Giorgi F (2019) Thirty years of regional climate modeling: Where are we and where are we going next? J Geophys Res 124:56965723. https://doi.org/10.1029/2018JD030094

Giorgi F, Jones C, Asrar GR (2006) Addressing climate information needs at the regional level: the CORDEX framework. Bull World Meteorol Organ 58:175-183

Gröger M, Dieterich C, Meier HEM, Schimanke S (2015) Thermal air-sea coupling in hindcast simulations for the North Sea and Baltic Sea on the NW European shelf. Tellus A 67:1. https:// doi.org/10.3402/tellusa.v67.26911

Gröger M, Arneborg L, Dieterich C, Höglund A, Meier HEM (2019) Summer hydrographic changes in the Baltic Sea, Kattegat and Skagerrak projected in an ensemble of climate scenarios downscaled with a coupled regional ocean-sea ice-atmosphere model. Clim Dyn 53:5945-5966. https://doi.org/10.1007/s0038 2-019-04908-9

Hagedorn R, Lehmann A, Jacob D (2000) A coupled high resolution atmosphere-ocean model for the BALTEX region. Meteorol Z 9(1):7-20

Harris I, Jones PD, Osborn TJ, Lister DH (2014) Updated high-resolution grids of monthly climatic observations-the CRU TS3.10 dataset. Int J Climatol 34:623-642. https://doi.org/10.1002/ joc. 3711

Herger N, Sanderson BM, Knutti R (2015) Improved pattern scaling approaches for the use in climate impact studies. Geophys Res Lett 42:3486-3494. https://doi.org/10.1002/2015GL063569

Höglund A, Pemberton P, Hordoir R, Schimanke S (2017) Ice conditions for maritime traffic in the Baltic Sea in future climate. Boreal Environ Res 22:245-265

Ho-Hagemann HTM, Gröger M, Rockel B, Zahn M, Geyer B, Meier HEM (2017) Effects of air-sea coupling over the North Sea and the Baltic Sea on simulated summer precipitation over Central Europe. Clim Dyn 49:3851. https://doi.org/10.1007/s0038 2-017-3546-8

Ho-Hagemann HTM, Hagemann S, Grayek S, Petrik R, Rockel B, Staneva J, Feser F, Schrum C (2020) Internal model variability in the regional coupled system model GCOAST-AHOI. Atmosphere 11:227. https://doi.org/10.3390/atmos11030227

Hosseinzadehtalaei P, Tabari H, Willems P (2018) Precipitation intensity-duration-frequency curves for central Belgium with an ensemble of EURO-CORDEX simulations, and associated uncertainties. Atmos Res 200:1-12. https://doi.org/10.1016/j. atmosres.2017.09.015

Huang J, Guan X, Ji F (2012) Enhanced cold-season warming in semiarid regions. Atmos Chem Phys Discuss 12(2):4627-4653. https ://doi.org/10.5194/acpd-12-4627-2012

$\mathrm{Hu} \mathrm{Z-Z,} \mathrm{Wu} \mathrm{Z} \mathrm{(2004)} \mathrm{The} \mathrm{intensification} \mathrm{and} \mathrm{shift} \mathrm{of} \mathrm{the} \mathrm{annual}$ North Atlantic Oscillation in a global warming scenario simulation. Tellus A 56:112-124. https://doi.org/10.111 1/j.1600-0870.2004.00050.x

IPCC (2013) The physical science basis. In: Stocker TF, Qin D, Plattner G-K, Tignor M, Allen SK, Boschung J, Nauels A, Xia Y, Bex V, Midgley PM (eds) Contribution of Working Group I to the fifth assessment report of the intergovernmental panel on climate change. Cambridge University Press, Cambridge, p 1535

Jacob D, Petersen J, Eggert B et al (2014) EURO-CORDEX new high-resolution climate change projections for European impact research. Reg Environ Change 14:563-578. https://doi. org/10.1007/s10113-013-0499-2

Jacob D, Kotova L, Teichmann C, Sobolowski SP, Vautard R, Donnelly C, Koutroulis AG, Grillakis MG, Tsanis IK, Damm A, Sakalli A, van Vliet MTH (2018) Climate impacts in Europe under + $1.5^{\circ} \mathrm{C}$ global warming. Earth's Future 6(2):264-285. https://doi. org/10.1002/2017ef000710
Jacob D, Teichmann C, Sobolowski S et al (2020) Regional climate downscaling over Europe: perspectives from the EURO-CORDEX community. Reg Environ Change. https://doi.org/10.1007/ s10113-020-01606-9

Jeworrek J, Wu L, Dieterich C, Rutgersson A (2017) Characteristics of convective snow bands along the Swedish east coast. Earth Syst Dyn 8:163-175. https://doi.org/10.5194/esd-8-163-2017

Jones P, Briffa K (1992) Global surface air temperature variations during the twentieth century: part 1, spatial, temporal and seasonal details. The Holocene 2(2):165-179

Karl TR, Nicholls N, Ghazi A (1999) Clivar/GCOS/WMO, Workshop on indices and indicators for climate extremes workshop summary. Clim Change 42:3-7

Kelemen FD, Primo C, Feldmann H, Ahrens B (2019) Added value of atmosphere-ocean coupling in a century-long regional climate simulation. Atmosphere 10(9):537. https://doi.org/10.3390/atmos 10090537

King AD, Karoly DJ (2017) Climate extremes in Europe at $1.5^{\circ}$ and $2^{\circ}$ of global warming. Environ Res Lett 12:114031. https://doi. org/10.1088/1748-9326/aa8e2c

Kjellström E, Ruosteenoja K (2007) Present-day and future precipitation in the Baltic Sea region as simulated in a suite of regional climate models. Clim Change 81:281-291. https://doi. org/10.1007/s10584-006-9219-y

Kjellström E, Döscher R, Meier HEM (2005) Atmospheric response to different sea surface temperatures in the Baltic Sea: coupled versus uncoupled regional climate model experiments. Hydrol Res 36(4-5):397-409. https://doi.org/10.2166/nh.2005.0030

Kjellström E, Nikulin G, Strandberg G, Christensen OB, Jacob D, Keuler K, Lenderink G, van Meijgaard E, Schär C, Somot S, Sørland SL, Teichmann C, Vautard R (2018) European climate change at global mean temperature increases of 1.5 and $2{ }^{\circ} \mathrm{C}$ above pre-industrial conditions as simulated by the EURO-CORDEX regional climate models. Earth Syst Dyn 9:459-478. https ://doi.org/10.5194/esd-9-459-2018

Knist S, Goergen K, Buonomo E, Christensen OB, Colette A, Cardoso RM, Fealy R, Fernández J, García-Díez M, Jacob D, Kartsios S, Katragkou E, Keuler K, Mayer S, van Meijgaard E, Nikulin G, Soares PMM, Sobolowski S, Szepszo G, Teichmann C, Vautard R, Warrach-Sagi K, Wulfmeyer V, Simmer C (2017) Land-atmosphere coupling in EURO-CORDEX evaluation experiments. J Geophys Res Atmos 122(1):79-103. https://doi. org/10.1002/2016jd025476

Kotlarski S, Keuler K, Christensen OB, Colette A, Déqué M, Gobiet A, Goergen K, Jacob D, Lüthi D, van Meijgaard E, Nikulin G, Schär C, Teichmann C, Vautard R, Warrach-Sagi K, Wulfmeyer V (2014) Geosci Model Dev 7:1297-1333. https://doi.org/10.5194/ gmd-7-1297-2014,2014

Lake I, Gutowski W, Giorgi F, Lee B (2017) CORDEX: climate research and information for regions. Bull Am Meteor Soc 98:ES189-ES192. https://doi.org/10.1175/BAMS-D-17-0042.1

Madec G, The NEMO Team (2012) "NEMO ocean engine": Note du Pole de modélisation de l'Institut Pierre-Simon Laplace, France, No 27, ISSN no 1288-1619

Mathis M, Mayer B, Pohlmann T (2013) An uncoupled dynamical downscaling for the North Sea: method and evaluation. Ocean Model 72:153-166. https://doi.org/10.1016/j.ocemo d.2013.09.004

Mathis M, Elizalde A, Mikolajewicz U (2017) Which complexity of regional climate system models is essential for downscaling anthropogenic climate change in the Northwest European Shelf? Clim Dyn 50:2637-2659. https://doi.org/10.1007/s0038 2-017-3761-3

Matte D, Larsen MAD, Christensen OB, Christensen JH (2019) Robustness and scalability of regional climate projections over 
Europe. Front Environ Sci 6:163. https://doi.org/10.3389/fenvs .2018 .00163

Meier HEM, Höglund A, Döscher R, Andersson H, Löptien U, Kjellström E (2011) Quality assessment of atmospheric surface fields over the Baltic Sea of an ensemble of regional climate model simulations with respect to ocean dynamics. Oceanologia 53:193-227

Meier HEM, Hordoir R, Andersson HC, Dieterich C, Eilola K, Gustafsson BG, Höglund A, Schimanke S (2012) Modeling the combined impact of changing climate and changing nutrient loads on the Baltic sea environment in an ensemble of transient simulations for 1961-2099. Clim Dyn 39:2421-2441. https://doi. org/10.1007/s00382-012-1339-y

Meier HEM, Edman MK, Eilola KJ, Placke M, Neumann T, Andersson $\mathrm{HC}$ et al (2018) Assessment of eutrophication abatement scenarios for the Baltic sea by multi-model ensemble simulations. Front Mar Sci 5:44. https://doi.org/10.3389/fmars.2018.0044

Meier HEM, Dieterich C, Eilola K, Gröger M, Höglund A, Radtke H, Saraiva S, Wåhlström I (2019) Future projections of recordbreaking sea surface temperature and cyanobacteria bloom events in the Baltic Sea. Ambio 48:1362-1376. https://doi.org/10.1007/ s13280-019-01235-5

Meinshausen M, Smith SJ, Calvin KV, Daniel JS, Kainuma MLT, Lamarque J-F, Matsumoto K, Montzka SA, Raper SCB, Riahi K, Thomson AM, Velders GJM, van Vuuren D (2011) The RCP greenhouse gas concentrations and their extension from 1765 to 2300. Clim Change (Special Issue). https://doi.org/10.1007/ s10584-011-0156-Z

Metzger MJ, Bunce RGH, Jongman RHG, Mücher CA, Watkins JW (2005) A climatic stratification of the environment of Europe. Glob Ecol Biogeogr 14:549-563. https://doi.org/10.1111/j.1466822X.2005.00190.X

Ouzeau G, Soubeyroux J-M, Schneider M, Vautard R, Planton S (2016) Heat waves analysis over France in present and future climate: application of a new method on the EURO-CORDEX ensemble. Clim Services 4:1-12. https://doi.org/10.1016/j.clise r.2016.09.002

Pätsch J, Burchard H, Dieterich C, Gräwe U, Gröger M, Mathis M, Kapitza H, Bersch M, Moll A, Pohlmann T, Su J, Ho-Hagemann HTM, Schulz A, Elizalde A, Eden C (2017) An evaluation of the North Sea circulation in global and regional models relevant for ecosystem simulations. Ocean Model. https://doi.org/10.1016/j. ocemod.2017.06.005

Peterson TC (2005) Climate change indices. WMO Bull 54(2):83-86

Peterson TC, Coauthors (2001) Report on the activities of the Working Group on climate change detection and related rapporteurs 1998-2001. WMO, Rep. WCDMP-47, WMO-TD 1071, Geneve, Switzerland, pp 143

Pfeifer S, Bülow K, Gobiet A, Hänsler A, Mudelsee M, Otto J, Rechid D, Teichmann C, Jacob D (2015) Robustness of ensemble climate projections analyzed with climate signal maps: seasonal and extreme precipitation for Germany. Atmosphere 6:677-698

Poan ED, Gachon P, Laprise R, Aider R, Dueymes G (2017) Investigating regional climate modeling added value in simulating North American winter storm tracks. Clim Dyn. https://doi. org/10.1007/s00382-017-3723-9

Potopová V, Štěpánek P, Zahradníček P, Farda A, Türkott L, Soukup J (2018) Projected changes in the evolution of drought on various timescales over the Czech Republic according to Euro-CORDEX models. Int J Climatol 38:e939-e954. https://doi.org/10.1002/ joc. 5421

Prein AF, Gobiet A, Suklitsch M, Truhetz H, Awan NK, Keuler K, Georgievski G (2013) Added value of convection permitting seasonal simulations. Clim Dyn 41:2655-2677. https://doi. org/10.1007/s00382-013-1744-6
Primo C, Kelemen FD, Feldmann H, Akhtar N, Ahrens B (2019) A regional atmosphere-ocean climate system model (CCLMv5.0clm7-NEMOv3.3-NEMOv3.6) over Europe including three marginal seas: on its stability and performance. Geosci Model Dev 12:5077-5095. https://doi.org/10.5194/ gmd-12-5077-2019

Rahman M, Sulis M, Kollet SJ (2015) The subsurface-land surface-atmosphere connection under convective conditions. Adv Water Resour 83:240-249. https://doi.org/10.1016/j.advwa tres.2015.06.003

Rajczak J, Schär C (2017) Projections of future precipitation extremes over Europe: a multimodel assessment of climate simulations. J Geophysl Res 122:10773-10800. https://doi.org/10.1002/2017J D027176

Riahi K, Gruebler A, Nakicenovic N (2007) Scenarios of long-term socio-economic and environmental development under climate stabilization. Technol Forecast Soc Chang 74(7):887-935

Riahi K, Rao S, Krey V et al (2011) RCP 8.5-a scenario of comparatively high greenhouse gas emissions. Clim Change 109:33. https ://doi.org/10.1007/s10584-011-0149-y

Ritchie J, Dowlatabadi H (2017a) The $1000 \mathrm{GtC}$ coal question: are cases of vastly expanded future coal combustion still plausible? Energy Econ 65:16-31. https://doi.org/10.1016/j.eneco .2017.04.015

Ritchie J, Dowlatabadi H (2017b) Why do climate change scenarios return to coal? Energy 140:1276-1291. https://doi.org/10.1016/j. energy.2017.08.083

Samuelsson P, Jones CG, Willen U, Ullerstig A, Golvig S, Hansson U, Jansson C, Kjellström E, Nikulin G, Wyser K (2011) The Rossby Centre Regional Climate model RCA3: model description and performance. Tellus A 63:4-23. https://doi.org/10.111 1/j.1600-0870.2010.00478.x

Schleussner C-F, Lissner TK, Fischer EM, Wohland J, Perrette M, Golly A, Rogelj J, Childers K, Schewe J, Frieler K, Mengel M, Hare W, Schaeffer M (2016) Differential climate impacts for policy-relevant limits to global warming: the case of $1.5{ }^{\circ} \mathrm{C}$ and $2{ }^{\circ} \mathrm{C}$. Earth Syst Dyn 7:327-351. https://doi.org/10.5194/ esd-7-327-2016

Schrum C, Hübner U, Jacob D, Podzun R (2003) A coupled atmosphere/ice/ocean model for the North Sea and the Baltic Sea. Clim Dyn 21(2):131-151

Sein DV, Mikolajewicz U, Gröger M, Fast I, Cabos W, Pinto JG et al (2015) Regionally coupled atmosphere-ocean-sea ice-marine biogeochemistry model ROM: 1 . Description and validation. J Adv Model Earth Syst 7:268-304. https://doi.org/10.1002/2014m s000357

Sein DV, Gröger M, Cabos W, Alvarez F, Hagemann S, de la Vara A, Pinto JG, Izquierdo A, Koldunov NV, Dvornikov AY, Limareva N, Martinez B, Jacob D (2020) Regionally coupled atmosphereocean-marine biogeochemistry model ROM: 2. Studying the climate change signal in the North Atlantic and Europe. J. Adv Model Earth Syst 1:1. https://doi.org/10.1029/2019MS001646

Soto-Navarro J, Jordá G, Amores A et al (2020) Evolution of Mediterranean Sea water properties under climate change scenarios in the Med-CORDEX ensemble. Clim Dyn 54:2135-2165. https:// doi.org/10.1007/s00382-019-05105-4

Teichmann C, Bülow K, Otto J, Pfeifer S, Rechid D, Sieck K, Jacob $\mathrm{D}$ (2018) Avoiding extremes: benefits of staying below $+1.5^{\circ} \mathrm{C}$ compared to $+2.0^{\circ} \mathrm{C}$ and $+3.0^{\circ} \mathrm{C}$ global warming. Atmosphere 9:115. https://doi.org/10.3390/atmos9040115

Teutschbein C, Seibert J (2012) bias correction of regional climate model simulations for hydrological climate-change impact studies: review and evaluation of different methods. J Hydrol 456457:12-29. https://doi.org/10.5167/uzh-67262 
Thomson AM, Calvin KV, Smith SJ et al (2011) RCP4.5: a pathway for stabilization of radiative forcing by 2100. Clim Change 109:77. https://doi.org/10.1007/s10584-011-0151-4

Tian T, Boberg F, Bssing CO, Hesselbjerg CJ, She J, co-authors (2013) Resolved complex coastlines and land-sea contrasts in a highresolution regional climate model: a comparative study using prescribed and modelled SSTs. Tellus A 65:19951. https://doi. org/10.3402/tellusa.v65i0.19951

Tian T, Su J, Boberg F, Yang S, Schmith T (2016) (2016), Estimating uncertainty caused by ocean heat transport to the North Sea: experiments downscaling EC-Earth. Clim Dyn 46:99-110. https ://doi.org/10.1007/s00382-015-2571-8

Tinker J, Lowe J, Holt J, Pardaens A, Wiltshire A (2015) Validation of an ensemble modelling system for climate projections for the northwest European shelf seas. Prog Oceanogr 138:211-137. https://doi.org/10.1016/j.pocean.2015.07.002

Tinker J, Lowe J, Pardaens A, Holt J, Barciela R (2016) Uncertainty in climate projections for the 21st century northwest European shelf seas. Prog Oceanogr 148:56-73. https://doi.org/10.1016/j. pocean.2016.09.003

Van Pham T, Brauch J, Dieterich C, Früh B, Ahrens B (2014) New coupled atmosphere-ocean-ice system COSMO-CLM/NEMO: assessing air temperature sensitivity over the North and Baltic Seas. Oceanologia 56:167-189. https://doi.org/10.5697/ oc. $56-2.167$

van Vuuren D, den Elzen M, Lucas P, Eickhout B, Strengers B, van Ruijven B, Wonink S, van Houdt R (2007) Stabilizing greenhouse gas concentrations at low levels: an assessment of reduction strategies and costs. Clim Change. https://doi.org/10.1007/s/10584 -006-9172-9

van Vuuren DP, Stehfest E, den Elzen MGJ et al (2011) RCP2.6: exploring the possibility to keep global mean temperature increase below $2{ }^{\circ} \mathrm{C}$. Clim Change 109:95. https://doi.org/10.1007/s1058 4-011-0152-3

Vautard R, Gobiet A, Jacob D et al (2013) The simulation of European heat waves from an ensemble of regional climate models within the EURO-CORDEX project. Clim Dyn 41:2555-2575. https:// doi.org/10.1007/s00382-013-1714-Z

Vautard R, Gobiet A, Sobolowski S, Kjellström E, Stegehuis A, Watkiss P, Mendlik T, Landgren O, Nikulin G, Teichmann C, Jacob D (2014) The European climate under a $2{ }^{\circ} \mathrm{C}$ global warming. Environ Res Lett 9:034006. https://doi.org/10.1088/17489326/9/3/034006

Wang S, Dieterich C, Döscher R, Höglund A, Hordoir R, Meier HEM, Samuelsson P, Schimanke S (2015) Development and evaluation of a new regional coupled atmosphere-ocean model in the North Sea and Baltic Sea. Tellus A 67:1. https://doi.org/10.3402/tellu sa.v67.24284

Wang X, Li J, Sun C, Liu T (2017) NAO and its relationship with the Northern Hemisphere mean surface temperature in CMIP5 simulations. J Geophys Res Atmos 122:4202-4227. https://doi. org/10.1002/2016JD025979

Wu M, Schurgers G, Rummukainen M, Smith B, Samuelsson P, Jansson C, Siltberg J, May W (2016) Vegetation-climate feedbacks modulate rainfall patterns in Africa under future climate change. Earth Syst Dyn 7:627-647. https://doi.org/10.5194/ esd-7-627-2016

Publisher's Note Springer Nature remains neutral with regard to jurisdictional claims in published maps and institutional affiliations. 